\title{
Taxonomic revision, phylogeny, and cyst wall composition of the dinoflagellate cyst genus Votadinium Reid (Dinophyceae, Peridiniales, Protoperidiniaceae)
} Gurdebeke Pieter R. ${ }^{1,{ }^{*}}$, Mertens Kenneth ${ }^{2}$, Pospelova Vera ${ }^{3}$, Matsuoka Kazumi ${ }^{4}$, Li Zhen ${ }^{3}$,
Gribble Kristin E. ${ }^{5}$, Gu Haifeng ${ }^{6}$, Bogus Kara ${ }^{7,8}$, Vrielinck Henk ${ }^{9}$, Louwye Stephen ${ }^{1}$

1 Department of Geology, Ghent University, Krijgslaan 281, S8, 9000 Ghent, Belgium.;

2 Ifremer, LER BO, Station de Biologie Marine, Place de la Croix, BP40537, F-29185 Concarneau

CEDEX, France.;

${ }^{3}$ School of Earth and Ocean Sciences, University of Victoria, PO Box 1700, STN CSC, Victoria, British

Columbia V8W 2Y2, Canada.;

${ }^{4}$ Institute for East China Sea Research (ECSER), 1551-7, Taira-machi, Nagasaki 851-2213, Japan;

5 Josephine Bay Paul Center for Comparative Molecular Biology and Evolution, Marine Biological

Laboratory, Woods Hole, MA, 02543, USA.;

${ }^{6}$ Third Institute of Oceanography, State Oceanic Administration, Xiamen, 361005, China;

7 International Ocean Discovery Program, Texas A\&M University, College Station, TX, 77845, USA.;

${ }^{8}$ Camborne School of Mines, University of Exeter, Penryn, Cornwall, UK TR10 9EZ;

${ }^{9}$ Department of Solid State Sciences, Ghent University, Krijgslaan 281, S1, B-9000 Gent, Belgium.

* Corresponding author : Pieter R. Gurdebeke, email address : Pieter.gurdebeke@ugent.be

\begin{abstract}
:
The taxonomy of the dinoflagellate cyst-based genus Votadinium has been in need of revision. This was accomplished here by integrating morphology, LSU rDNA sequences, and cyst wall composition analyses through micro-Fourier transform infrared spectroscopy. Three new species, Votadinium pontifossatum, $V$. rhomboideum and $V$. reidii, were described as cyst stages of Protoperidinium paraoblongum, $P$. quadrioblongum, and $P$. steidingerae, respectively. A previously undescribed type of ornamentation was reported for $V$. pontifossatum. A fourth new species was assigned to $V$. concavum. Furthermore, Lejeunecysta psilodora Benedek (=Lejeunecysta psuchra Matsuoka), was re-described as $V$. psilodora and the holotype re-illustrated, as was done for the holotype of $V$. spinosum Reid. New illustrations were provided for $V$. elongatum and $V$. nanhaiense. LSU rDNA sequences of $V$. concavum revealed its placement in the Oceanica section of the genus Protoperidinium, supporting earlier evidence that the Oceanica section and the cyst based genus Votadinium form a monophyletic clade. Thus, Votadinium could be considered the cyst equivalent of the motile-defined Oceanica section. The cyst walls of Votadinium spinosum, V. calvum and V. pontifossatum are built from carbohydrate-based macromolecules with $\mathrm{N}$-containing functional groups in agreement with the heterotrophic nature of their motile stage. Comparison with related genera Trinovantedinium and Quinquecuspis reveals that the species and genera can be separated based on cyst wall composition, supporting the phylogeny based on molecular data and/or ecological differences. Furthermore, Trinovantedinium applanatum spectra unexpectedly show an additional absorption at $1510 \mathrm{~cm}^{-1}$ indicating an aromatic group that is commonly reported for sporopollenin and not seen in dinoflagellate cysts so far. This study stabilizes the taxonomy
\end{abstract}


of the cyst genus Votadinium, clarifies its relationship to the Oceanica section of Protoperidinium, and further supports the application of whole cyst wall chemistry in helping address problems in dinoflagellate cyst taxonomy and ecology.

Keywords : taxonomy, dual nomenclature, dinocyst, ornamentation, micro-FTIR, cyst wall composition, sporopollenin 


\section{Introduction}

The life cycle of $\sim 200$ living dinoflagellate species involves a cyst stage or hypnozygote (e.g., Head 1996). The existence of these two morphologically-distinct stages, motile and cyst, has led to the usage of a dual nomenclature (i.e., paleontological/biological; e.g., Ellegaard et al. 2018). The relationship between the stages is increasingly better understood through incubation experiments and molecular analyses (e.g., Sarai et al. 2013; Gu et al. 2015; Mertens et al. 2017a). However, this duality persists and is sanctioned by the international nomenclatural code (e.g., Head et al. 2016) because of the differing approaches of biologists, working mainly on the motile stages, and paleontologists that work primarily with the cyst stages. In particular, a cyst-based taxonomy is indispensable for paleontologists working with extinct taxa where no biological approach or molecular identification is possible.

The dinoflagellate cyst genus Lejeunecysta, originally Lejeunia, see Artzner and Dörhöfer (1978), was erected by Gerlach (1961) with the Oligocene age Lejeunecysta hyalina (Gerlach) Artzner et Dörhöfer as the type species. The description given by Gerlach encompasses cysts with a bilateral symmetry, a pentagonal ambitus with one apical and two antapical horns, no reflection of tabulation but with an indication of a spiral cingulum and a sulcus. The genus was emended by Kjellström (1972, p. 467) to include features of the archeopyle, and by Lentin and Williams (1976, p. 68-69) who detailed the wall structure. Stover and Evitt (1978, p.111) emended the genus to include only forms with autophragma (i.e. excluding cavate species). The emendation by Bujak et al. (1980) to stress the symmetrical position of the archeopyle relative to the middorsal line was rejected by Head (1993). The genus currently comprises 39 species (Williams et al. 2017). 
Reid (1977) erected the genus Votadinium to include dinoflagellate cysts similar to Lejeunecysta but without an expression of the cingulum as an indentation. Two species were described from modern surface sediments around the British Isles: Votadinium calvum (type species) and Votadinium spinosum. Later, He and Sun (1991) included two more species: Votadinium elongatum and Votadinium nanhaiense recovered from Quaternary sediments around the Spratly Islands (South China Sea). Although the genus was considered illegitimate and superfluous by Lentin and Williams (1993), it was retained by later authors (Head et al. 2016; Williams et al. 2017).

Votadinium calvum has been frequently recorded in marine Quaternary sediments (e.g., Zonneveld et al. 2013), and Reid (1977) related the cyst form to the cysts of motilebased species Protoperidinium oblongum (Aurivillius) Parke et Dodge reported by Wall and Dale (1968). Wall and Dale (1968) illustrated two other distinct morphotypes that they also related to $P$. oblongum. Since then, $P$. oblongum has been shown to be a species complex, and has been split into several closely related species that previously were considered varieties of P. oblongum: Protoperidinium quadrioblongum (=P. oblongum var. symmetricum Dangeard), Protoperidinium latidorsale and Protoperidinium paraoblongum (=Protoperidinium oblongum var. inaequale Dangeard) and their respective cysts. However, new cyst-based species were not erected (Sarai et al. 2013).

In the subdivision of the large genus Protoperidinium, the P. oblongum complex belongs to the Oceanica section. This section was defined by Jörgensen (1912) based on thecate morphology with a typical Protoperidinium tabulation (Po, X, 4', 1-3a, 7"', 4c(3+t), $\left.6 s, 5^{\prime \prime \prime}, 2^{\prime \prime \prime}\right)$, an ortho $1^{\prime}$ and a usually four-sided (quadra) second intercalary plate. Balech (1974) adopted the original definition of the Oceanica section, but the shape and number of anterior intercalary plates were not a stable taxonomic characteristic as they significantly 
differ in number and shape (Abé 1981). Instead, details from the sulcal area and the nature of the antapical horns were considered more stable characteristics (Abé 1981).

Harland (1982), stressing the importance of cyst morphology, specifically the archeopyle, in dinoflagellate classification, called this ortho-quadra configuration "section Votadinium". Although the hierarchies in classifications based on cysts and motile stages are different, Harland (1982) found that both systems were in agreement and that different cyst morphologies reflected the sections within the genus Protoperidinium.

Molecular phylogenies of Protoperidinium increasingly support the morphological classifications based on motile stages and their reconciliation with cyst-based taxonomy (Matsuoka and Kawami 2013; Sarai et al. 2013; Mertens et al. 2017c). In these phylogenies, species of the Oceanica section form a clade, sister to a "Protoperidinium sensu stricto" clade which includes the cyst species Trinovantedinium applanatum (cyst of Protoperidinium shanghaiense) and Quinquecuspis concreta (cyst of Protoperidinium leonis) (Mertens et al. 2017c) that possess morphological similarities to Votadinium cysts (Table 1). For the genus Lejeunecysta, which also possesses morphological similarities, the phylogenetic position is unknown so far, since molecular data are lacking, although Protoperidinium latissimum, the cyst of which could be assigned to Lejeunecysta, belongs to the Conica clade 1 (Gu et al. 2015).

Cyst walls of dinoflagellates are composed of dinosporin, which has been suggested, predominantly through micro-Fourier transformed infrared (FTIR) spectroscopic data, to be a suite of complex carbohydrate-based macromolecules (e.g., Versteegh et al. 2012; Bogus et al. 2014; Mertens et al. 2015). The overall geochemical composition of the cyst wall seems mainly determined by the phylogeny (e.g., Gurdebeke et al. 2018a) and by the nutritional strategy of the dinoflagellate species (e.g., Mertens et al. 2017b, c; Luo et al. 2018). However, the number of dinoflagellate cyst species from surface sediments for which spectra are 
available remains very small (a total of 20 in published or accepted publications), and an expanded sampling of taxa is desirable to further explore its utility for chemotaxonomy and an increased understanding of dinoflagellate ecology.

Overall, the taxonomy of genus Votadinium is in need of revision and stabilization. This is done here by emending the genus and re-evaluating type material (holotypes and type region sediments) of attributable species. Furthermore, new LSU rDNA sequences of Votadinium species allow further evaluation of the molecular phylogeny and the relation between motile and cyst-based taxonomies. Micro-FTIR spectroscopy was used to characterize the cyst wall chemistry of selected Votadinium species and to explore the concept of chemotaxonomy for dinoflagellate cysts, by comparison with the cyst composition of related (Protoperidinium sensu stricto clade) genera Trinovantodinium and Quinquecuspis.

\section{Material and methods}

\subsection{Sampling and imaging}

Cyst specimens were studied from surface, sediment trap and core samples that were mostly used in previous studies (Table 2). These include samples from the coastal waters of southern Vancouver Island (Krepakevich and Pospelova 2010), Saanich Inlet (Price and Pospelova 2011, Mertens et al. 2012, Price et al. 2016), western Vancouver Island (Gurdebeke et al. 2017, 2018b, in prep.), the Vilaine estuary (France; Mertens et al. 2009), the South China Sea (Li et al., in prep.) and Bohai Sea. The reader is referred to the respective publications for details on sampling and sediment processing. Specimens of the cysts of Protoperidinium steidingerae from the culture study of Gribble et al. (2009) on Vineyard Sound (Massachusetts, USA) samples were re-examined (Table 2).

New transmitted light microscopy (LM) photomicrographs of a topotype of Lejeunecysta psuchra from Akkeshi Bay were made from slides studied by Matsuoka (1987); 
the holotype could not be located. The holotype of Lejeunecysta psilodora Benedek 1972 is housed in the repository of the Institute of Geology and Mineralogy (Köln University, Germany), and was restudied. Reid's (1977) holotype of Votadinium spinosum, stored in the repository at the Micropalaeontology Laboratory (University of Sheffield, UK), was also observed.

The photomicrographs were produced with a Zeiss Axio Imager A1 equipped with a MRc 5 camera in the Department of Geology (Ghent University, Belgium) and Nikon Eclipse 80i microscopes and coupled Nikon DS Camera Heads (DS-Fi1)/DS with Camera Control Units DS-L2 in the Paleoenvironmental Laboratory (the School of Earth and Ocean Sciences) at the University of Victoria (Canada). The photomicrographs of L. psuchra were made with an Olympus BX51 light microscope with a digital camera (Qimaging, Burnaby, Canada) and the $V$. spinosum holotype was photographed at the University of Sheffield with an Infinity 1 camera mounted on a Meiji MT 5300H microscope.

For scanning electron microscope (SEM) images, single cysts were picked from the residue, mounted on polycarbonate membrane filters (Millipore, Billerica, MA, USA, GTTP Isopore, $0.22 \mu \mathrm{m}$ pore size) and sputter coated with Au. The images were made with a Zeiss SIGMA300 Gemini field emission SEM at the Station de Biologie Marine (Ifremer, Concarneau, France).

\subsection{Synonymy}

The John Williams Index of Palaeopalynology (Riding et al. 2012), based at the British Museum (Natural History), was consulted as a base for establishing species synonymies. This data base includes entries for Lejeunecysta psilodora, L. psuchra, Votadinium calvum and V. spinosum. The illustrated specimens were re-interpreted along the lines of the taxonomy 
proposed here. The references in the synonymy lists can be consulted in Williams et al. (2017) and are not reproduced here for the sake of brevity.

\subsection{Cyst wall composition analysis}

For micro-FTIR analysis, cysts of Votadinium spinosum, V. calvum, V. pontifossatum, Quinquecuspis concreta, Trinovantedinium applanatum and T. pallidifulvum were extracted from surface sediment samples from Kyuquot Sound (see Gurdebeke et al. 2017 for details), Saanich Inlet (see Mertens et al. 2012 for details), Izmir Bay (see Mertens et al. 2015 for details), Diana Lagoon (Corsica, France) (see Luo et al. 2017 for details), German Wadden Sea (see Bogus et al. 2014 for details) and the Vilaine Estuary in Brittany (see Gurdebeke et al. 2018a for details) (Table 2).

The palynological residues were processed as described in Gurdebeke et al. (2018b). The residues were ultrasonicated for $30 \mathrm{~s}$ and rinsed three times with organic solvents (methanol and dichloromethane, 1:1 in volume) and MilliQ water over a $20 \mu \mathrm{m}$ mesh-size filter to remove polar and apolar compounds that might have adhered to the cyst walls. Visually clean, empty individual whole cysts were manually isolated, placed on an Au-coated mirror and dried. Specimens were analyzed with a Bruker Hyperion 2000 microscope coupled to a Bruker Vertex 80v FTIR spectrometer in the Department of Solid State Sciences (Ghent University, Belgium). The objective magnification of the microscope was set at $15 \times$ and the aperture at $100 \times 100 \mu \mathrm{m}$. The combination of detector (liquid $\mathrm{N}_{2}$ cooled MCT), source (Globar) and beamsplitter (KBr) settings restricted the effective infrared spectral range examined to $\sim 4000-650 \mathrm{~cm}^{-1}$. All presented spectra were recorded in reflection mode, at a resolution of $2 \mathrm{~cm}^{-1}$, and averaged over 100 scans.

Data were analyzed with the OPUS $^{\odot}$ software (Bruker 2014). The presented absorbance spectra were obtained after background (direct reflection on the $\mathrm{Au}$ mirror) 
subtraction, atmospheric correction and baseline correction with a rubberband method using polynomes. Functional groups were identified based on comparison with Colthup et al. (1990) and published data (e.g., Bogus et al. 2014; Cárdenas et al. 2004). Data reduction was performed as a principal component analysis (PCA) using PAST 3.2 (Hammer et al. 2001).

\subsection{LSU sequencing and molecular phylogeny}

Votadinium cysts were isolated from recent sediments of the South China Sea, East China Sea and Bohai Sea to 96 well plates for germination with $\mathrm{f} / 2-\mathrm{Si}$ medium (Guillard and Ryther 1962) at $20^{\circ} \mathrm{C}, 90 \mu \mathrm{E} \cdot \mathrm{m}^{-2} \cdot \mathrm{s}^{-1}$ under a $12: 12 \mathrm{~h}$ light:dark cycle. Germinated cells or living cysts were rinsed several times in sterilized distilled water, broken by squeezing the coverslip above and then transferred into a polymerase chain reaction (PCR) tube. The single cell/cyst was used as the template to amplify $\sim 1,430$ bp of the LSU rDNA (D1-D6 domains) using the primers D1R (forward, 5'-ACCCGCTGAATTTAAGCATA-30) (Scholin et al. 1994), 281483R (reverse, 5'-GCTACTACCACCAAGATCTGC-30) (Daugbjerg et al. 2000). A $50 \mu \mathrm{l}$ PCR cocktail containing $0.2 \mu \mathrm{M}$ primers, PCR buffer, $50 \mu \mathrm{M}$ dNTP mixture and $1 \mathrm{U}$ of Ex Taq DNA polymerase (Takara, Dalian, China) was subjected to 35 cycles using a Mastercycler PCR (Eppendorf, Hamburg, Germany). The PCR protocol was initial denaturation for $3.5 \mathrm{~min}$ at $94^{\circ} \mathrm{C}$, followed by 35 cycles of $50 \mathrm{~s}$ denaturation at $94^{\circ} \mathrm{C}, 50 \mathrm{~s}$ annealing at $45^{\circ} \mathrm{C}$ and $80 \mathrm{~s}$ extension at $72^{\circ} \mathrm{C}$, plus a final extension of $10 \mathrm{~min}$ at $72^{\circ} \mathrm{C}$.

The amplified products were run on a $1 \%$ agarose gel. Positive bands were excised and purified using a DNA extraction kit (Sangon, Shanghai, China). The purified PCR products were sequenced directly using the ABI Big-Dye dye-terminator technique (Applied Biosystems, Foster City, California, USA), according to the manufacturer's recommendations.

Newly obtained LSU rDNA sequences were incorporated into a systematically representative set of dinoflagellates available in GenBank. Sequences were aligned using the 
MAFFT v7.110 (Katoh and Standley 2013) online program (http://mafft.cbrc.jp/alignment/server/) with default settings. Alignments were manually checked with BioEdit v. 7.0 .5 (Hall 1999). For Bayesian inference (BI), the program jModelTest (Posada 2008) was used to select the most appropriate model of molecular evolution with Akaike Information Criterion (AIC). Bayesian reconstruction of the data matrix was performed using MrBayes 3.2 (Ronquist and Huelsenbeck 2003) with the best-fitting substitution model $(\mathrm{GTR}+\mathrm{G})$. Four Markov chain Monte Carlo (MCMC) chains ran for 2,000,000 generations, sampling every 100 generations. The first $10 \%$ of burn-in trees were discarded. A majority rule consensus tree was created to examine the posterior probabilities of each clade. Maximum likelihood (ML) analyses were conducted with RaxML v7.2.6 (Stamatakis 2006) on the T-REX web server (Boc et al. 2012) using the model GTR+G. Node support was assessed with 1000 bootstrap replicates.

\section{Results}

\subsection{Systematic paleontology}

Division Dinoflagellata(Bütschli) Fensome et al.

Class Dinophyceae Pascher

Order Peridiniales Haeckel

Family Protoperidiniaceae Bujak and Davies

Subfamily Protoperidinioideae (Autonym)

Genus Votadinium Reid, emend.

Type species. Votadinium calvum Reid 1977, p. 444, pl. 2, fig. 21.

Original diagnosis (Reid 1977). "Peridinoid-shaped cysts with a rounded apex or elongate apical horn and with two antapical, rounded horns or lobes separated by an antapical 
depression which may be deep or shallow. Test compressed dorsoventrally, no evidence for a girdle. Archeopyle intercalary."

Emended diagnosis. Dorsoventrally compressed peridinioid cysts consisting of a single wall layer with a rounded apex or an elongated apical horn and two rounded or elongated, blunt antapical horns separated by a deep or shallow antapical concavity. The equatorial area is usually the broadest part of the cyst. The thin wall $(\sim 1 \mu \mathrm{m})$ is pale brown to dark brown and can be smooth or microgranular and can have a discrete surface ornamentation or spines. No cingular indentation present, such as thickened or elevated cingular lists, although the cingulum is sometimes delineated by the absence of ornamentation. Sulcal depression present to absent, and may bear flagellar scars. Archeopyle intercalary, reflecting a 1 a or 2 a plate, basically hexagonal or pentagonal sometimes with rounded corners, positioned dorsally or involving the entire apical section of the cyst.

Stratigraphic range. Eocene to recent.

Votadinium calvum Reid, 1977

P1. 1, Fig. 1-7.

\section{Synonymy.}

1882 Peridinium divergens: Bergh, Pl. 5, Fig. 40.

1965 Peridinium cyst-form 3: Wall, Fig. 13-15.

1968 Peridinium oblongum (Aurivillius) Paulsen: Wall and Dale, Pl. 1, Fig. 25-28.

1975 Cyst of Peridinium oblongum: Davey and Rogers, Pl. 1, Fig. 11.

1977 Votadinium calvum gen. nov., sp. nov.: Reid, p. 444, Pl. 2, Fig. 21-23.

1982 Protoperidinium (Protoperidinium sect. Votadinium) oblongum: Harland, p. 380, Pl. 40, Fig. 10-12.

1983 Cyst of Protoperidinium oblongum: Dale, Fig. 9. 
1987 Cyst of Protoperidinium oblongum (Aurivillius) Parke et Dodge: Akselman, Pl. 2, Fig.

1.

1987 Votadinium carvum [sic]: Matsuoka, Pl. 7, Fig. 1-8.

1988 Votadinium calvum Reid: Bint, p. 335, Fig. 3K.

1992 Votadinium calvum Reid: de Vernal et al., p. 328, Pl. 7, Fig. 3.

1993 Cyst of Protoperidinium oblongum: Nehring, Fig. 5N.

1994 Cyst of Protoperidinium oblongum: Ellegaard et al., Fig. 58.

1994 Cyst of Protoperidinium oblongum: Nehring, Fig. 1Q-R.

1994 Votadinium carvum [sic.]: Matsuoka and Lee, Pl. 2, Figs. 6-8.

1996 Cyst of Protoperidinium oblongum: Nehring, Fig. 12A-D.

1997 Cyst of Protoperidinium oblongum: Sonneman and Hill, p. 165, Fig. 26.

1999 Votadinium calvum Reid: Rochon et al., p. 52, Pl. 14, Fig. 1-2.

2000 Protoperidinium oblongum type a: Rubino et al., Fig. 2p-q.

2003 Cyst of Protoperidinium oblongum: Morquecho and Lechuga-Devéze, Fig. 5.

2004 Protoperidinium oblongum: Harland et al., Pl. 1, Fig. 1-2.

2004 Votadinium calvum Reid: Pospelova et al., Pl. 2, Fig. 11a.

2004 Votadinium calvum Reid: Radi and de Vernal, Pl. 1, Fig. 10.

2005 Votadinium calvum: Pospelova et al., Fig. 7-6.

2006 Votadinium calvum: Brenner, Fig. 4I.

2006 Cyst of Protoperidinium oblongum: Fuji and Matsuoka, Fig. 4d.

2007 Votadinium calvum: Prasad et al., Fig. 3J.

2010 Votadinium calvum: Limoges et al., Pl. 3, Fig. 12.

2010 Votadinium calvum: Pospelova and Kim, Pl. 2, Fig. G.

2010 Cyst of Protoperidinium oblongum: Satta et al., Pl. 3, Fig. e.

2011 Votadinium calvum: Price and Pospelova, Pl. 4, Fig. 4. 
2012 Cyst of Protoperidinium oblongum: Furio et al., Fig. 2-25.

2012 Protoperidinium oblongum: Srivilai et al., Fig. 2-P.

2016 Votadinium calvum: Bringué et al., Pl. 3, Fig. 5.

Motile stage equivalent. Protoperidinium latidorsale Balech, according to Sarai et al. (2013).

Remarks. The specimen in Pl. 1, Figs. 1-3 shows the general characteristics of the species: broad (wider than long) heart-shaped cyst with a thin wall and broadly rounded antapical horns separated by a shallow antapical concavity. The surface may be smooth (P1. 1, Figs. 47) or microgranular (Pl. 1, Figs. 1-3). The SEM images (Pl. 1, Figs. 4-7) show that the cyst presented here is deformed, which somewhat alters the appearance of its outline in ventral or dorsal view (e.g. depth of the antapical concavity or the shape of the horns). It is not known how general this phenomenon is, however, and whether the deformation took place before settling, in the sediment or during processing. The defining characteristics of the species remain valid. The SEM images (Pl. 1, Fig. 4-7) also show sutural delineations suggesting that the entire apex is involved in archeopyle formation or that the apex is not clearly distinguishable. The archeopyle reflects a hexagonal dorsal intercalary plate (cf. the large 1a plate, Sarai et al. 2013). Although the apex is involved in the formation of the hexagonal archeopyle, it probably does not involve apical plates, as more than sutures would be expected in that case. A flagellar scar is present on the right side of the sulcal depression (Pl. 1, Fig. 5, 7).

Comparison with other species. Votadinium calvum differs from $V$. spinosum by the absence of spines, from $V$. rhomboideum by its well-rounded shape, and from all other species in the genus by having the apex involved in the archeopyle. Specimens of Quinquecuspis concreta have been incorrectly identified as $V$. calvum in cases of poor cyst orientation (e.g., Matsuoka 1987, Pl. 8, Figs. 1-3; McMinn 1991, Pl. 1, Figs. 6 and 8). 
Distribution and stratigraphic range. The modern distribution is global. Reports published with illustrations are mainly limited to latest Pleistocene to recent sediments. Older occurrences have been reported up to Burdigalian age (Londeix and Jan du Chêne 1998) but these are not illustrated so the identification cannot be confirmed.

Votadinium concavum sp. nov.

Gurdebeke, Mertens, Matsuoka, Gu, Louwye

Pl. 1, Figs. 8-10.

\section{Synonymy.}

2011 Cyst of Protoperidinium sp.: Attaran-Fariman et al., Fig. 12-15.

2012 Votadinium calvum: Liu et al., Fig. 3v.

Motile stage equivalent. Unidentified.

Holotype. SEM stub of WN142 from the Bohai Sea (3955.864'N, 11944.128'E).

Repository. Third Institute of Oceanography, State Oceanic Administration, Xiamen, 361005, China.

Diagnosis. Broad cysts with concave outline on both epi- and hypocyst and shallow antapical concavity. Cyst wall smooth and pale brown. Archeopyle seems to partly involve the apex.

Description. The concavity of the ambitus may be less obvious in some specimens (Pl. 1, Fig. 8). No obvious flagellar scar was observed (Pl. 1, Fig. 8), but the sulcal depression is often roughened, which might obliterate such structure.

Remarks. The small number of cysts observed does not allow an extensive formal description. This, along with the identification of the motile stage using incubation experiments, will be the focus of future work.

Dimensions. Length $65-85 \mu \mathrm{m}$; width $65-85 \mu \mathrm{m}(\mathrm{N}=2)$, with an average $\mathrm{L} / \mathrm{W}$ of 0.96 . 
Comparison. Votadinium concavum mostly resembles $V$. calvum, but is broader and typically has a less rounded and more concave outline. $V$. concavum has a more typical concave outline and a more shallow antapical concavity than than V. rhomboideum. Absence of ornamentation distinguishes $V$. concavum from $V$. spinosum and $V$. pontifossatum. The lower $\mathrm{L} / \mathrm{W}$ distinguishes $V$. concavum from $V$. elongatum, $V$. nanhaiense, $V$. pontifossatum and $V$. reidii. Distribution and stratigraphic range. In modern sediments from the East China Sea and Bohai Sea. Based on the synonymy also in off coast Iran and in the Yellow Sea.

Votadinium elongatum He and Sun, 1991

Pl. 2, Figs. 1-6.

\section{Synonymy.}

1965 Peridinium sp. cyst-form 1: Wall, Fig. 8-9.

2004 "Pre-excysted protoperidinioid": Kawamura, Fig. 16.

2007 "Protoperidinioid dinocysts (Trinovantedinium sp.)": Prasad et al., Fig. 3-K.

Motile stage equivalent. Unknown.

Diagnosis (He and Sun 1991, p. 297). "Cyst proximate, elongate peridinioid, compressed dorsoventrally with cingular area rounded. Epicyst bearing a conspicuous apical horn, cylindrical to conical. Hypocyst extending straight-backwards two blunt antapical horns of approximately equal size, forming U-shaped antapical concavity. Wall thin, $0.5-1 \mu \mathrm{m}$ thick, single-layered or with two layers closely appressed, light brown to pale yellow in color, surface smooth or with several secondary folds. Paracingulum sometimes faintly expressed or marked, on the type specimen, by a transverse equatorial fold. Parasulcus deep, restricted to hypocyst and broader posteriorly. Archeopyle, when present, intercalary, subcircular in outline, formed by loss of large paraplate 2a. Operculum free or lying within cyst.” 
Dimensions. He and Sun (1991, p. 297): Length 70-77 $\mu \mathrm{m}$, width 40-49 $\mu \mathrm{m}$, apical horn length 6-10 $\mu \mathrm{m}$, antapical horns $11-14 \mu \mathrm{m}$ and $16 \mu \mathrm{m}$ long, respectively. Own measurements: Length 69.9-79.2 $\mu \mathrm{m}$, width 40.4-49.8 $\mu \mathrm{m}$, apical horn 13.4-14.7 $\mu \mathrm{m}$, antapical horns: $14.1-17.0 \mu \mathrm{m}, \mathrm{L} / \mathrm{W} 1.58-1.73(\mathrm{~N}=2)$.

Remarks. The identification of $V$. elongatum with the cyst of Protoperidinium oblongum in Wall and Dale (1968, Pl. 1, Figs. 23-24) by He and Sun (1991) is not followed here, since the difference in morphology is clear (e.g., rounded instead of straight, more conspicuous apical horn). As such, the motile stage equivalent of $V$. elongatum remains unknown. The original illustrations are reproduced in Pl. 2, Figs. 1, 2 as this publication is not widely available.

Comparison. Distinguished from other Votadinium species by the large size, elongated (high L/W) and rounded body shape, and rounded archeopyle. Votadinium elongatum is comparable to $V$. reidii in size, but $V$. reidii typically has a straight outline and a hexagonal archeopyle.

Distribution and stratigraphic range. This species has been rarely reported. It was recorded in recent sediments from around the Spratly Islands (type area) and the Sunda Shelf (Kawamura 2004), the southwestern waters off Taiwan and the shelf off Hainan Island (South China Sea), and from the west coast of India (Prasad et al. 2007). Wall (1965) recorded $V$. elongatum from Woods Hole (Massachusetts, USA).

Votadinium nanhaiense He and Sun, 1991.

Pl. 2, Figs. 7-15.

\section{Synonymy.}

2003 Votadinium nanhaiense: Jurkschat, p. 14, Pl. 13, Fig. 4-7.

2013 Protoperidinium sp. 2: Narale et al., Fig. 2n.

Motile stage equivalent. Unknown. 
Diagnosis (He and Sun 1991, p. 297). "Cyst proximate, elongate peridinioid, always with shoulders, compressed dorsoventrally, equatorial area prominently bulging outwards. Epicyst and hypocyst of approximately equal size. Epicyst bell-shaped with a triangular apical horn, blunt at tip. Hypocyst trapezoidal, with a gently arc-shaped antapical margin and two strongly divergent antapical horns of nearly the same size and blunt at free ends. Autophragm pale yellow in color, surface smooth or folded. Both paracingulum and parasulcus faint or absent. Archeopyle very large, intercalary, rounded six-sided or subcircular in outline, and situated in the mid-dorsal surface just below apex. Operculum free or falling into cyst cavity."

Dimensions. He and Sun (1991, p. 298): Length 65-75.8 $\mu \mathrm{m}$; width 49-53.5 $\mu \mathrm{m}$; apical horn length 9-11 $\mu \mathrm{m}$; antapical horn length 6.7-11 $\mu \mathrm{m}$. Own measurements: Length 59.7 (72.1) $79.4 \mu \mathrm{m}$, width 44.4 (54.4) $67.3 \mu \mathrm{m}$, apical horn 10.4 (11.5) $12.1 \mu \mathrm{m}$, antapical horns 11.5 (14.7) 16.8, L/W $1.17(1.33) 1.47(\mathrm{~N}=4)$.

Remarks. The original photograph of the holotype is reproduced in Pl. 2, Figs. 7-9 as this publication is not widely available.

Comparison. The divergent antapical horns and epicystal shoulders clearly distinguish $V$. nanhaiense from other species within the genus.

Distribution and stratigraphic range. He and Sun (1991) described Votadinium nanhaiense from recent sediments from the South China Sea (type area). The species was also recorded in recent sediments from the Arabian Sea by Jurkschat (2003), off the coast of India by Narale et al. (2013) and, as this study shows, Holocene sediments from the South China Sea.

Votadinium pontifossatum sp. nov. Gurdebeke, Mertens, Pospelova, Matsuoka, Li and Louwye Pl. 3, Figs. 1-13.

\section{Synonymy.}


1972 “Votadinium cyst form 1": Reid, Pl. 11, Fig. 13-15.

2011 Cyst of Protoperidinium oblongum: Price \& Pospelova, Pl. 4, Fig. 3.

2013 Cyst of Protoperidinium paraoblongum: Sarai et al., Pl. 2, Fig. 1-3, Pl. 5.

Motile stage equivalent. Protoperidinium paraoblongum Sarai et al., 2013, according to Sarai et al. (2013).

Holotype. Patricia Bay, Saanich Inlet, SIPB-EOS313-09 core 4-5 cm sample, UVic 2009179-1 (48³9.997'N, 12329.014'W), EF V37/0, Pl. 3, Figs. 1-4.

Repository. Royal Belgian Institute of Natural Sciences (RBINS, Brussels), accession $\mathrm{n}^{\circ}$ IRSNB b7155.

Etymology. From Latin pons, meaning bridge, and fossa, meaning small depression, in reference to the ornamentation described below.

Diagnosis. The brownish cysts have a dorso-ventrally compressed pentagonal ambitus. The length is greater than the width $(\mathrm{L} / \mathrm{W}=1.18, \mathrm{~N}=9)$. The epicyst has straight or slightly convex sides with a pronounced apical horn. The antapical concavity is deep and U-shaped and the antapical horns elongated. The ornamentation consists of small rod-like elements in circular depressions, covering the entire cyst including the operculum. Archeopyle saphopylic and pentagonal, though occasionally the entire apical part (the horn) can be missing. The cingular area is sometimes devoid of ornamentation.

Description. The thin-walled (less than $1 \mu \mathrm{m}$ ) cysts are fragile and often strongly folded and torn (Pl. 3, Figs. 5, 9). The right antapical horn is often longer and broader than the left antapical horn. The ornamentation consists of small (length $0.83(1.01) 1.14 \mu \mathrm{m}$, width 0.18 (0.20) $0.24 \mu \mathrm{m}, \mathrm{N}=8$ ) rod-like elements bridging a circular crater-like depression in the cyst wall (Pl. 3, Fig 10). The depressions do not form holes. The rods are mostly fused with the cyst wall but sometimes appear as unattached elements lying in the depression (Pl. 3, Fig. 10). The rods are randomly oriented and distributed over the cyst's wall $\left(11 / 100 \mu \mathrm{m}^{2}, \mathrm{~N}=5\right)$. This 
kind of wall ornamentation is unique and is here named a pontifossate wall texture, in reference to the ornamentation resembling a bridge spanning a depression.

Remarks. The characteristic surface ornamentation of Votadinium pontifossatum sp. nov. is visible in the illustrations of the cyst of Protoperidinium paraoblongum provided by Sarai et al. (2013), and was described as "granules" in that publication. The ornamentation was also observed on a number of cysts from a sediment trap (UVic 2009-179-1 in Price and Pospelova, 2011) and surface sediments in Saanich Inlet (Pl. 3, Figs. 5-7, 9), as well as in the Holocene sediment samples from Kyuquot Sound (Pl. 3, Fig 8). Other examples of this species were documented from the Kiel Bight (German Wadden Sea) and the South China Sea. When describing the new species Votadinium calvum, Reid (1977) stated "careful observation under phase contrast showed 'crater-like' pits on many specimens," which relates to the ornamentation described here, though no rods were reported. The ornamentation is not illustrated by Reid (1977) but Figs. 13-15 on Plate 11 in Reid (1972) depicts the ornamented type. Some specimens observed here indeed have a number of craters that lack rods, but quantitative information on the range of this presence-absence is not available at present (e.g. Pl. 3, Fig. 11-13).

Dimensions. Sarai et al. (2013): length 65 (80) $90 \mu \mathrm{m}$, width 63 (72) $80 \mu \mathrm{m}$, L/W 1.19-1.39 $(\mathrm{N}=4)$. Our measurements on the cysts from the NE Pacific are: Holotype: length $85 \mu \mathrm{m}$, width $73 \mu \mathrm{m}$, range: length 71.6 (79.2) $86.6 \mu \mathrm{m}$, width 61.1 (67.7) $75.7 \mu \mathrm{m}, \mathrm{L} / \mathrm{W} 1.09$ (1.18) $1.33(\mathrm{~N}=9)$.

Comparison. This species differs from all other Votadinium species by its characteristic surface ornamentation. In addition, the new species is distinguished from $V$. calvum and $V$. spinosum by a differing L/W (generally $>1$ ), and from $V$. psilodora in that the latter has a more rounded shape and lower L/W. Votadinium elongatum generally has a higher L/W. Votadinium nanhaiense differs in having typical shoulders in the epicyst outline, diverging 
antapical horns and a triangular apical horn. V. reidii has more pronounced apical and antapical horns.

Distribution and stratigraphic range. Holocene, surface and trap sediments from Vancouver Island waters in Canada, as well as from recent sediments from Omura Bay in Japan (Sarai et al. 2013), Fangchenggang Port (South China Sea), and coastal waters from Europe (United Kingdom and northern Germany).

Votadinium psilodora (Benedek, 1972) comb. nov. Pl. 4, Figs. 1-11.

\section{Synonymy.}

1972 Lejeunecysta psilodora: Benedek, Pl. 6, Fig. 5.

1981 Selenopemphix nephroides, pars: Benedek and Sarjeant, Fig. 8, 3-4.

1987 Lejeunecysta psuchra: Matsuoka, Pl. 9, Fig. 7-8.

1988 Votadinium calvum Reid: Bint, Fig. 3-J.

1988 Lejeunecysta psilodora (Benedek) Artzner and Dorhofer: Gruas-Cavagnetto and Barbin, Pl. V, Fig. 12-13.

1989 Cyst of Protoperidinium oblongum: Kojima, Fig. 6-2.

2000 Protoperidinium sp. 1: Cho, p. 24, Pl. 2, Fig. 8.

2004 Lejeunecysta psuchra: Louwye et al., Fig. 10r-s.

2010 Cyst of Protoperidinium spp.: Pospelova et al., P1. 5, Fig. 5.

Motile stage equivalent. Unknown.

Holotype. Mid-Oligocene of Tönisbergen (Germany). The holotype is stored in the repository of the Institute of Geology and Mineralogy, University of Köln, Germany. Re-illustrated here in Pl. 4, Figs. 1-8. 
Remarks. No diagnostic characteristics separate 'Lejeunecysta psuchra' Matsuoka from ' $L$. psilodora' Benedek. Lejeunecysta psuchra is slightly smaller (length 80-84 $\mu$ m; width 68-72 $\mu \mathrm{m}$, Matsuoka 1987) than Lejeunecysta psilodora (length 90-96 $\mu \mathrm{m}$, width 75-78 $\mu \mathrm{m}$, Benedek 1972). Therefore, synonymy of Lejeunecysta psilodora and Lejeunecysta psuchra is proposed, with Lejeunecysta psuchra as the junior synonym. Furthermore, no expression of the cingulum as an equatorial indentation of the cyst body, was observed. As the presence of a cingulum was the main characteristic that distinguishes Votadinium from Lejeunecysta, Lejeunecysta psilodora is transferred to the genus Votadinium. Also, the archeopyle index of 'L. psilodora' is too large and the antapical horns are wide and rounded, as previously noted by Stover and Evitt (1978, p. 112); these are characteristics more suited for Votadinium. The holotype of $V$. psilodora is re-illustrated in Pl. 4, Figs. 1-8. The holotype of 'L. psuchra' was not found, but observations were made on cysts from the type material ( $\mathrm{Pl}$. 4, figs 9-11).

Comparison. Votadinium psilodora is different from Votadinium reidii in having a more rounded outline and (ant)apical horns, and from V. pontifossatum by the absence of a pontifossate ornamentation. $V$. psilodora is also distinguished from $V$. calvum, V. spinosum, $V$. rhomboideum and cyst of $P$. venustum by the dorsal position of the archeopyle.

Distribution and stratigraphic range. Mid-Oligocene deposits from Tönisbergen (NW Germany; Benedek 1972), Pliocene deposits from Belgium (Louwye et al. 2004) and late Quaternary sediments from Japan (Matsuoka 1987, 1992). Williams and Bujak (1977, p. 30) reported L. psilodora as having its highest occurrence in their "Epicephalopyxis indentata assemblage," which ranges into the early Miocene. They did not provide illustrations, so the identification cannot be confirmed.

Votadinium reidii sp. nov.

Gurdebeke, Mertens, Pospelova, Matsuoka, Gribble and Louwye 


\section{Pl. 5, Figs. 1-13.}

\section{Synonymy:}

1965 Peridinium sp. cyst-form 1: Wall

1966 P. oblongum (Aur.) Cleve: Wall and Dale, fig 6

1968 Cyst of Protoperidinium oblongum (Aurivillius) Paulsen: Wall and Dale, Pl. 1, Figs. $23-24$.

2005 Protoperidinium oblongum: Pospelova et al., Fig. 6.8.

2009 Cyst of Protoperidinium steidingerae: Gribble et al., Fig. 4, 5.

Motile stage equivalent: Protoperidinium steidingerae, according to Gribble and Anderson (2006) and Gribble et al. (2009).

Holotype. Cyst from culture experiment based on material sampled at Martha's Vineyard Coastal Observatory, Vineyard Sound, Massachusetts (41 '19.5'N, 70³4.0' W; MV0923-PO-1 in Gribble et al. 2009) mounted on SEM stub GR-2, illustrated in Pl. 5, Figs; 1-3.

Repository: Royal Belgian Institute of Natural Sciences (RBINS, Brussels), accession $n^{\circ}$ IRSNB b7156.

Etymology. Named in honor of P.C. Reid, who erected the genus Votadinium.

Diagnosis: Brownish elongated cyst with smooth wall. Outline with straight edges, especially on the left side of the cyst; right cyst variably more rounded. Apical horn variable, ranging from long and narrow to small and rounded. Antapical horns ranging from elongated to wellrounded; right antapical horn mostly longer than the left one. Sulcal area with flagellar scar. Archeopyle hexagonal in dorsal position, not involving apex.

Description. There is considerable variability in the cyst shape, ranging from elongated with straight edges (Pl. 5, Figs. 3, 4) to nearly equidimensional and more rounded (Pl. 5, Figs. 1013). The archeopyle shape is consistent, however, and the outline of the left side of the cyst is always straight. The archeopyle reflects a $2 \mathrm{a}$ intercalary plate. 
Dimensions (Gribble et al. 2009). Length 68 (83) $95 \mu \mathrm{m}$, width 48 (59) $68 \mu \mathrm{m}, \mathrm{L} / \mathrm{W}: 1.2$ (1.4) $1.8(\mathrm{~N}=30)$.

Remarks. Most of the information available stems from incubation experiments (Gribble et al. 2009). Palynological records are rare and limited to the same region (Pospelova et al. 2005). The relationship of $P$. steidingerae with the morphologically closely related motilebased species $P$. concinna and $P$. novella described by Faust (2006) in the subgenus Testeria is unclear (Gribble et al. 2009, p. 102) and needs further investigation.

Comparison. Votadinium elongatum has a more rounded outline and archeopyle. It differs from $V$. calvum and $V$. spinosum by having a straight outline and a length that is generally greater than the width, and a dorsal archeopyle. Votadinium spinosum and V. pontifossatum are different because they have ornamentation. The apex is not involved in the operculum, which differentiates it from $V$. rhomboideum.

Distribution and stratigraphic range: Rare species, presently known from cultures based on material recovered from Vineyard Sound (Massachusetts, USA) and from surface sediments from New England (USA).

Votadinium rhomboideum sp. nov.

Gurdebeke, Mertens, Pospelova, Matsuoka, Li and Louwye

Pl. 6, Figs. 1-14.

Synonymy.

1983 Cyst of Protoperidinium oblongum: Dale, Fig. 11-12.

1987 Protoperidinium oblongum: Baldwin, Fig. 14.

2000 Cyst of Protoperidinium oblongum (Aurivillius) Parke \& Dodge: Della Tommasa et al., Pl. 1, Fig. 7.

2000 Protoperidinium oblongum type b: Rubino et al., Fig. 2r. 
2001 Cyst of Protoperidinium oblongum: Dale, Fig. 1-7, 8.

2004 Cyst of Protoperidinium oblongum: Joyce, p. 178, Fig. 18.

2004 "Pre-excysted protoperidinioid cyst": Kawamura, Fig. 15.

2004 Cyst of Protoperidinium oblongum: Morquecho and Lechuga-Devéze, Fig. 12.

2004 Cyst of Protoperidinium oblongum, Orlova et al., Fig. 58.

2006 Cyst of Protoperidinium oblongum: Fujii and Matsuoka, Fig. 4-e.

2008 Cyst of Protoperidinium oblongum: Ribeiro and Amorim, Pl. 2, Fig. b.

2008 Votadinium calvum: Vilanova et al., Pl. 1, Fig. J.

2010 Votadinium calvum: Pospelova et al., Pl. 6, Fig. 3.

2010 Votadinium calvum: Uzar et al., Fig. 25.

2011 Votadinium carvum [sic.]: Aydin et al., Fig. 27.

2011 Votadinium calvum: Pasuram et al., Pl. 1, Fig. 8.

2011 Votadinium calvum: Price and Pospelova, Pl. 4, Fig. 4.

2013 Cyst of Protoperidinium oblongum, Orlova and Morozova, Fig. 4f, g.

2013 Cyst of Protoperidinium quadrioblongum: Sarai et al., Pl. 3, Fig. 1-4.

Motile stage equivalent. Protoperidinium quadrioblongum Sarai et al., 2013, according to

Sarai et al. (2013).

Holotype. Patricia Bay, Saanich Inlet $\left(4^{\circ} 39.005^{\prime} \mathrm{N}, 123^{\circ} 29.027^{\prime} \mathrm{W}\right.$, station PB 3 in Mertens et al., 2012), surface sediments, UVic 2012-197-1 (EF R20/4, label to the right), Pl. 6, Figs. $1-8$.

Repository. Royal Belgian Institute of Natural Sciences (RBISN, Brussels), accession $\mathrm{n}^{\circ}$ IRSNB b7157.

Diagnosis. Brownish cysts, rhomboidal in outline in ventral or dorsal view, length and width comparable. Epi- and hypocyst sides are straight or slightly concave, yielding the cyst an angular outline. Cyst wall smooth. Two rounded antapical horns rounded and generally 
symmetrical, sometimes right horn slightly broader. Sulcal area incised and carrying flagellar scar. Antapical concavity deeply incised and U-shaped. Archeopyle (type IA, 2a) large, trapezoidal, saphopylic and involving the apex.

Description. Rhomboidal/pentagonal cyst with straight outlines. Cyst width and length comparable, with $\mathrm{L} / \mathrm{W}=0.98(0.87-1.05, \mathrm{~N}=4)$, although the length is obscured when the apex is lost with archeopyle. Cyst is smooth and has a single wall.

Dimensions. Sarai et al. (2013): Length 61 (70) $84 \mu \mathrm{m}$, width 59 (67) $80 \mu \mathrm{m}, \mathrm{L} / \mathrm{W}$ 0.88-1.05 (N=4). Own measurements: Holotype: length $65.4 \mu \mathrm{m}$, width $62.2 \mu \mathrm{m}$; Range: length $65.4-$ $73.1 \mu \mathrm{m}$, width 62.2-69.5 $\mu \mathrm{m}, \mathrm{L} / \mathrm{W} 0.95(\mathrm{~N}=2)$.

Remarks. Votadinium rhomboideum is not identical to the cyst of Protoperidinium oblongum (Aurivillius) Paulsen reported by Wall and Dale (1968, Pl. 1, Fig. 29), as was suggested by Sarai et al. (2013).

Comparison. V. rhomboideum sp. nov. differs from $V$. calvum and $V$. spinosum in that it has a higher L/W ratio and straight outlines for the epi and hypocyst. It lacks ornamentation, which distinguishes it from $V$. spinosum and $V$. pontifossatum, and it differs from $V$. pontifossatum and $V$. reidii in having the apex involved in the operculum. It can be distinguished from $V$. nanhaiense and $V$. elongatum by the position of the archeopyle and general outline. Finally, $V$. concavum has concave outlines of the epi- and hypocyst, rather than straight edges.

Distribution and stratigraphic range. The species was observed here in the South China Sea and Saanich Inlet. Based on the synonymy list, Votadinium rhomboideum occurs globally, but with most reports from the North Atlantic and North Pacific domains.

Votadinium spinosum Reid, 1977

Pl. 7, Fig. 1-15.

\section{Synonymy:}


1965 Peridinium sp. (cysts-form 5): Wall, p. 307, Fig. 16.

1967 Cyst of Peridinium claudicans Paulsen: Wall and Dale, p. 350, Pl. 1, Fig. R.

1968 Peridinium claudicans Paulsen: Wall and Dale, p. 273, Pl. 2, Fig. 1-2.

1975 Cyst of Peridinium claudicans Paulsen: Davey and Rogers, p. 217, Pl. 1, Fig. 10.

1977 Votadinium spinosum Reid: Reid, p. 445-446, Pl. 2, Fig. 24-26.

1985 Votadinium spinosum Reid: Matsuoka, p. 58-59, Pl. 14, Fig. 1-6.

1987 Votadinium spinosum: Matsuoka, p. 65-66, Pl. 14, Fig. 1-5.

1987 Cyst of Protoperidinium claudicans: Akselman, Pl. 1, Fig. 7-9.

1989 Votadinium spinosum; Kojima, Fig. 6.5.

1990 Cyst of Protoperidinium claudicans (Paulsen) Balech: Bolch and Hâllegraeff, p. 183, Fig. 25.

1992 Votadinium spinosum Reid: Matsuoka, p. 51, Pl. 2, Fig. 9.

1993 Cyst of Protoperidinium claudicans; Nehring, Fig. 5-J.

1994 Votadinium spinosum Reid: Matsuoka, Pl. 2, Fig. 3a-b.

1996 Cyst of Protoperidinium claudicans Qi et al., p. 96, Pl. 3, Fig. Q.

1997 Cyst of Protoperidinium claudicans: Nehring, p. 313, Fig. 17.

1998 Cyst of Protoperidinium claudicans: Montresor et al., Fig. 3a.

2000 Votadinium spinosum: Cho, p. 27, Pl. 3, Fig. 1.

2000 Cyst of Protoperidinium claudicans: Ishikawa and Taniguchi, Fig. 4-J.

2000 Protoperidinium claudicans: Rubino et al., p. 276, Fig. 2 g.

2002 Votadinium spinosum Reid: Prauss, Pl. 3, Fig. 7.

2003 Protoperidinium claudicans: Morquecho and Lechuga-Devéze, Fig. 3.

2004 Cyst of Protoperidinium claudicans: Harland et al., Pl. 1, Fig. 3.

2004 Cyst of Protoperidinium claudicans: Joyce, p. 176, Fig. 14a,b.

2004 Protoperidinium claudicans (Paulsen) Balech: Orlova et al., Figs. 44-46. 
2004 Votadinium spinosum: Pospelova et al., Pl. 2, Fig. 12.

2004 Votadinium spinosum: Radi and de Vernal, Pl. 1, Fig. 11.

2005 Protoperidinium claudicans: Joyce et al., Fig. 11.

2005 Votadinium spinosum: Pospelova et al., Fig. 7.7.

2007 Votadinium spinosum: Cremer et al., Fig. 191-192.

2008 Votadinium spinosum: Vilanova et al., Pl. 1, Fig. K.

2010 Votadinium spinosum: Krepakevich and Pospelova, Pl. $3 \mathrm{f}$.

2010 Votadinium spinosum: Limoges et al., Pl. 3, Fig. 11.

2010 Votadinium spinosum: Matsuoka and Shin, Fig. 2E.

2010 Votadinium spinosum: Pospelova et al., Pl. 6, Fig. 4.

2010 Votadinium spinosum: Satta et al., Pl. 2, Fig. n.

2010 Votadinium spinosum: Shin et al., Fig. 4-H.

2010 Votadinium spinosum: Uzar et al., Fig. 26.

2011 Votadinium spinosum: Aydin et al., Fig. 12a,b.

2011 Cyst of Protoperidinium claudicans: D'Silva et al., Fig. 2.15.

2011 Votadinium spinosum: Price and Pospelova, Pl. 4, Fig. 5.

2012 Votadinium spinosum: Candel et al., Fig. 2.8.

2012 Cyst of Protoperidinium claudicans: Furio et al., Fig. 2.17.

2012 Protoperidinium claudicans: Srivilai et al., Fig. 2Q.

2013 Votadinium spinosum: Bringué et al., p. 41, Pl. 3, Fig. 6.

2013 Votadinium spinosum: Candel et al., Pl. 2, Fig. 6.

2013 Votadinium spinosum: Limoges et al., Pl. 2, Fig. 4.

2013 Cyst of Protoperidinium claudicans: Narale et al., Fig. 3g.

2013 Protoperidinium claudicans (Paulsen) Balech: Orlova and Morozova Fig. 3n-o.

2016 Votadinium spinosum Bringué et al., p. 805, Pl. 3, Fig. $6 .$. 
2018 Votadinium spinosum Reid: Matsuoka et al., p. 128, Fig. 5.g.

Motile stage equivalent. Protoperidinium claudicans (Paulsen 1907) Balech 1974, according to Reid (1977, p. 445).

Remarks. The holotype of Reid (1977) was re-photographed and is illustrated here for the purpose of completeness (Pl. 7, Fig. 1-4). It shows a broad (wider than long) heart-shaped cyst with broadly rounded antapical horns separated by a shallow antapical concavity and a rounded apex. The thin smooth wall is ornamented with short (3-7 $\mu \mathrm{m}$; Reid 1977) solid spines. There is a large $2 \mathrm{a}$ archeopyle, which may involve apical plates. These general characteristics are also visible in the SEM image (Pl. 7, Fig. 13), where the archeopyle is open and the operculum has been shed. The cyst wall and spines appear to be microgranular, and the solid spines have minute fenestrae at their bases (Pl. 3, Figs. 5-7). It is possible that $V$. spinosum represents a species complex, as suggested by Matsuoka and Head (2013). This hypothesis needs to be further evaluated through cyst-theca and morphological studies.

Comparison. This species differs from all other Votadinium species in having a granular wall and bearing spines, and from V.psilodora, V. elongatum, V. nanhaiense, V. pontifossatum and $V$. reidii in having a $\mathrm{L} / \mathrm{W}<1$ and the archeopyle involving the apical part of the cyst.

\subsection{Sequencing and molecular phylogeny}

Three sequences were retrieved from cysts from surface sediments in the South China Sea: two for Votadinium concavum ([genbank numbers]), and one for Votadinium calvum (cyst of Protoperidinium latidorsale, [genbank number]). The molecular phylogeny based on LSU rDNA is shown in Fig. 1. Within the phylogeny, the three new sequences are placed in the Oceanica clade of Protoperidinium, which is formed by $P$. latidorsale (motile stage of Votadinium calvum), P. paraoblongum (V. pontifossatum), P. steidingerae (V. reidii), P. claudicans (V. spinosum), P. quadrioblongum (V. rhomboideum) and P. depressum (no cyst 
known). The sequence of $P$. latidorsale clusters with the known molecular data of this species, while the sequences of Votadinium concavum form a sister cluster to P. latidorsale. The Oceanica clade forms a clade with maximal support (Fig. 1).

\subsection{Cyst wall chemistry}

A total of 19 spectra were measured and representative spectra are shown in Fig. 2: three specimens of Votadinium spinosum (M9S9 and M12S13 from Kyuquot Sound, M1S8 from Izmir Bay), two of $V$. calvum (MXS20 and MXXS5 from Saanich Inlet), one of $V$. pontifossatum (MXS8 from Saanich Inlet), eight specimens of Quinquecuspis concreta (MXS3, MXS7, MXS16 and MXS17 from Saanich Inlet, M9S5 and M9S7 from Kyuquot Sound and M13S15 from Corsica), one specimen of T. pallidifulvum (M6S4 form the German Wadden Sea), and four specimens of Trinovantedinium applanatum (M4S3 and M4S33 from the Vilaine estuary, M1S7 from Izmir Bay and M6S13 from the German Wadden Sea). The main absorptions are summarized in Table 3. The broad peak between 3600 and $3000 \mathrm{~cm}^{-1}$ is due to $\mathrm{OH}$-stretching with the maximum mostly centered around $3270 \mathrm{~cm}^{-1}$. The centering of the absorption at $3270 \mathrm{~cm}^{-1}$, along with a faint shoulder at $3100 \mathrm{~cm}^{-1}$, is indicative of $\mathrm{N}-\mathrm{H}$ stretching, although further detail in this region is obscured by the broad peak. Two consistent absorptions are present at 2925 and $2860 \mathrm{~cm}^{-1}$ that indicate aliphatic methyl and methylene $\left(\mathrm{CH}_{3}\right.$ and $\left.\mathrm{CH}_{2}\right)$ stretching.

In the fingerprint region $\left(1700-800 \mathrm{~cm}^{-1}\right)$, the dominant absorptions for most specimens are between 1700 and $1500 \mathrm{~cm}^{-1}$. The amide II band, located between 1550 and $1590 \mathrm{~cm}^{-1}$, is one of the dominant absorptions in all spectra. Absorptions around $1660 \mathrm{~cm}^{-1}$ (amide I band) is the strongest absorption in Votadinium spinosum spectra, while it is a secondary peak or shoulder for $Q$. concreta and $T$. applanatum. Unusually for dinoflagellate cysts, a consistent absorption is recorded for the cysts of T. applanatum at $1510 \mathrm{~cm}^{-1}$. 
The spectral region from 1500 to $1200 \mathrm{~cm}^{-1}$ is, in most cases, less pronounced. A consistent small absorption or shoulder at $1255 \mathrm{~cm}^{-1}$ indicates N-H bending, as does the 1312 $\mathrm{cm}^{-1}$ absorption (amide III). The latter also contains absorptions characteristic for C-N stretching. Absorptions at 1420 and $1370 \mathrm{~cm}^{-1}$ indicate $\mathrm{C}-\mathrm{H}$ bending.

The absorptions between 1200 and $1030 \mathrm{~cm}^{-1}$, which are minor in the $V$. spinosum spectra but more prominent in the others, arise from C-O-type stretching. Finally, absorption at the amide $\mathrm{V}$ band $\left(\sim 700 \mathrm{~cm}^{-1}\right)$ consistently occurs in all spectra.

A PCA analysis on the fingerprint region of the spectra $\left(1700-800 \mathrm{~cm}^{-1}\right.$, see Bogus et al. 2014) yields PC1 and PC2 that represent $72.9 \%$ of the variability and reveals that each of the species' spectra cluster, regardless of sample location (Fig. 3).

\section{Discussion}

\subsection{Taxonomy, phylogeny and evolution of the genus Votadinium}

The previously poorly understood taxonomy of the cyst genus Votadinium was emended in this study to include brown peridinioid cysts without expression of a cingulum and with a dorso-apical archeopyle. Based on morphology, nine species were attributed to Votadinium, which are schematically represented in Fig. 4. A cyst that should possibly also be assigned to Votadinium has been reported for Protoperidinium brochii by Blanco (1989), but new observations are required to evaluate such a placement. Perhaps further species may be transferred to Votadinium, e.g. Lejeunecysta sabrina of Reid (1977), but new observations are needed for this.

Besides the species reported in this study, the Oceanica section includes other species such as P. oceanicum, P. larsenii, P. murrayi (Balech 1974; Taylor 1976; Abé 1981; PhanTan et al. 2017), for which molecular data or information on possible cyst stages are lacking (Gribble and Anderson 2006). Cysts belonging to Votadinium psilodora, V. elongatum and 
Votadinium nanhaiense most probably have motile stages assignable to Protoperidinium (also suggested by Matsuoka 1987, p. 61 for 'Lejeunecysta psuchra'). Incubation experiments and/or molecular analysis can resolve this relationship.

The new molecular data confirm earlier phylogenetic studies (e.g., Gribble and Anderson 2006; Sarai et al. 2013; Gu et al. 2015; Mertens et al. 2017c) that, based on LSU rDNA sequences, the Oceanica section of the genus Protoperidinium (i.e. P. latidorsale, $P$. claudicans, $P$. steidingerae, $P$. paraoblongum, $P$. quadrioblongum and $P$. depressum) forms a monophyletic clade (Fig. 1). In addition, the topology of these earlier phylogenetic trees is confirmed (e.g. Mertens et al. 2017c).

The placement of the cysts of the Oceanica section Protoperidinium species into a single genus (Votadinium) indicates that the morphological classification of the cysts reflects the phylogenetic relationships of the motile stage species (Harland 1982). It must be noted however, that for other cyst-based genera related to Protoperidinium, the same conclusions cannot always be drawn. For example, Mertens et al. (2017c) found that two species in the cyst-based genus Selenopemphix have motile stages belonging to different clades within the genus Protoperidinium. It was argued that, since the morphological difference between both cyst species is considerable, they belong to different cyst genera. Also, the cyst-based genus Brigantedinium is known to be polyphyletic with respect to motile stages in the genus Protoperidinium (Matsuoka et al. 2006). Compared with other protoperidinioid cyst genera, Brigantedinium species have relatively few characteristics (e.g., archeopyle) upon which to base classification (Matsuoka 2002). That explains the previously unrecognized diversity within this group. Other clades were found within the Protoperidinium genus that have morphologically similar cysts; for example, the cyst genera Trinovantedinium and Quinquecuspis in the Conica-section (Mertens et al., 2017c). Overall, this indicates coherence 
between the differing cyst- and motile-based taxonomic concepts. Future discoveries of cyst new stages for species of the Oceanica section will provide a further test for this.

From an evolutionary point of view, Bujak and Davies (1983) hypothesized that Votadinium psilodora from Oligocene age sediments (as 'Lejeunecysta psilodora') is an early representative of the Votadinium evolutionary lineage, represented in their scheme by Votadinium spinosum and Votadinium calvum. This scheme is updated in Fig. 5. Cyst morphology in the Oceanica/Votadinium clade is characterized by the absence of cingular excavation, which was present in ancestral forms like Senegalinium or Phelodinium (cf. Bujak and Davies 1983) and was retained in the extant Lejeunecysta, Trinovantedinium and Quinquecuspis. The earliest representative, $V$. psilodora, had a dorsally positioned archeopyle, which also is an ancestral trait. In some of the younger members of the clade (i.e. $V$. calvum, $V$ concavum, $V$ spinosum, $V$ rhomboideum), the archeopyle has shifted to include at least a part of the apical region. Judging from the molecular phylogeny (Fig. 1), this would have taken place multiple times. The records of all Votadinium species except for $V$. psilodora and possibly $V$. calvum are limited to the Holocene and Upper Pleistocene. Votadinium calvum has been reported from Miocene sediments (Londeix and Jan Du Chêne 1998), but that observation could not be confirmed since it was not illustrated. Votadinium psilodora consistently occurs from the late Eocene onwards. This mainly Neogene and younger occurrence of Votadinium cysts is in line with other protoperidiniacean groups, appearing after the decline of the Deflandreaceae in the Miocene (Bujak and Davies 1983). The late appearance of other Votadinium species may be due to a late radiation in the Plio/Pleistocene or poor preservation in the geological record. Though a poor preservation of peridinioid cysts was suggested by Zonneveld et al. (1997), the presence of e.g. Votadinium psilodora in Oligocene deposits shows that there are settings that allow exquisite preservation (Pl.4, Fig. 1-8). The Plio/Pleistocene is known as a period of intense global environmental change (e.g., 
Lisiecki and Raymo 2007; De Schepper et al. 2014), offering a drive for evolutionary radiations. This radiation may also be related to enhanced prey availability, since dinoflagellates of the 'P. oblongum' species complex are known to feed on diatoms (Jacobson and Anderson 1986; Sherr and Sherr 2007), which had their highest diversities during this interval (e.g., Lewituss et al. 2018). More research is needed on the Votadinium fossil record and on the feeding habits and molecular phylogeny of Oceanica clade species to support this tentative evolutionary scenario. The morphological evolution of the motile stages of the Oceanica section started with the divergence from an ancestral Protoperidinium with an ortho $1^{\prime}$ plate and three anterior intercalary plates, from which species with ortho-quadra arrangement diverged to form the Oceanica clade (Yamaguchi et al. 2006). A reduction in the number of anterior intercalary plates to just one has taken place in $P$. latidorsale and $P$. steidingerae, in line with the general trend of plate reduction in dinoflagellate evolution (e.g, Bujak and Williams 1981).

\subsection{Cyst wall chemistry of Votadinium and related genera}

The cyst wall composition of Votadinium spinosum, V. calvum, V. pontifossatum, Trinovantedinium pallidifulvum and Quinquecuspis concreta are broadly consistent with the dinosporin compositions measured by Bogus et al. (2014) for cysts of heterotrophic dinoflagellates; that is, a carbohydrate-based macromolecule with nitrogen-containing functional groups. This result is also consistent with the known heterotrophic nature of the corresponding motile stages belonging to the genus Protoperidinium. The spectrum of $T$. pallidifulvum reported here differs from that of Mertens et al. (2017c), measured from cysts from the same sample location. Their spectrum shows a strong absorption peak around 850 $900 \mathrm{~cm}^{-1}$ while the spectrum reported here has its maximum absorption in the amide II (1570 $\mathrm{cm}^{-1}$ ) band (Fig. 2, Table 3). It is at present not known whether this might be due to different 
FTIR methods or to other factors (e.g., ecologic or taphonomic). More measurements are needed to resolve this, highlighting the need for a more systematic cataloguing of cyst wall chemistry.

The absorption at $1510 \mathrm{~cm}^{-1}$ in Trinovantedinium applanatum is the first record of this aromatic absorption in a dinoflagellate cyst. All reported spectra were measured from specimens prepared identically, and the $1510 \mathrm{~cm}^{-1}$ absorption was measured for specimens from different locations, so this is a species-specific feature. This is the most prominent absorption in the spectra of specimens from Germany and Izmir, and is clearly different from the amide II band in other specimens (sharper) and represents the $\mathrm{C}=\mathrm{C}$ bond of single aromatic rings. This absorption has been indicative of sporopollenin (Watson et al. 2007; Jardine et al. 2015). Interestingly, Trinovantedinium applanatum is the only marine species with a transparent cyst wall that is known to be produced by a heterotrophic dinoflagellate (Reid 1977; Gu et al. 2015), and the absorptions characteristic for nitrogen-containing functional groups are present. Thus, this result both illustrates the utility of micro-FTIR in revealing the nutritional strategy of a species, as well as showing, for the first time, that there may be a sporopollenin-like component in some dinoflagellate cyst walls.

The PCA ordination of compositional data (Fig. 3) indicates that at least part of the cyst wall composition is species-specific. The remaining variability is arguably assigned to environmental or taphonomic differences, since specimens from the same location often plot closer to each other than specimens of the same species from other locations (e.g., the $T$. applanatum specimens from Brittany and the Q. concreta specimens from $\mathrm{BC}$ ), or perhaps to cryptic speciation (Fig. 3). This compositional separation is further support for the taxonomy implied by morphology and molecular phylogeny and increases the potential of micro-FTIR in taxonomic studies (i.e. chemotaxonomy). For dinoflagellate cysts, this chemotaxonomy has 
up to now been underexplored despite a similar approach being used successfully for other organic walled microfossils such as grass pollen (Julier et al. 2016).

\section{Conclusions}

The taxonomy of the dinoflagellate cyst genus Votadinium was stabilized in this study. The genus Votadinium previously had included four species: Votadinium calvum (cyst of Protoperidinium latidorsale), Votadinium spinosum (cyst of P. claudicans), Votadinium elongatum and Votadinium nanhaiense. V. elongatum and V. nanhaiense were re-illustrated from South China Sea (type region) material and the holotype of $V$. spinosum was reillustrated. Additionally, the cysts 'Lejeunecysta psuchra' and 'Lejeunecysta psilodora' were re-studied, found to be synonymous, and transferred to the genus Votadinium as V.psilodora; the holotype was also re-illustrated.

Furthermore, two new Votadinium species, V. pontifossatum and V. rhomboideum, were erected here to encompass the cysts of Protoperidinium paraoblongum and Protoperidinium quadrioblongum, respectively, and a new type of ornamentation was described for $V$. pontifossatum. Another new species, V. reidii, was erected for the cyst of Protoperidinium steidingerae (Gribble et al. 2009), and a new cyst was described as $V$. concavum.

LSU rDNA sequences of the motile stage of $V$. concavum and a new sequence of $P$. latidorsale confirmed placement of these taxa in the Oceanica clade. As a consequence, the genus Votadinium includes all of the cysts produced by Protoperidinium species belonging to the Oceanica section reported by Sarai et al. (2013). Cyst-based taxonomy thus reflected the taxonomy of the motile-stage based on morphology and molecular phylogeny.

The cyst wall chemistry of $V$. spinosum, $V$. calvum and $V$. pontifossatum and related species Quinquecuspis concreta, Trinovantedinium applanatum and T. pallidifulvum was 
evaluated using micro-FTIR spectroscopy. It is characterized in all but $T$. applanatum by a carbohydrate-based macromolecule with nitrogen-containing functional groups, consistent with the heterotrophic nature of the dinoflagellates involved. The spectra of Trinovantedinium applanatum indicate the presence of single aromatic rings, previously found in sporopollenin, and demonstrated for the first time in a dinoflagellate cyst species. This suggests that it is possible there is a sporopollenin-like component to the dinosporin comprising T. applanatum. This is an exciting finding, but will require additional investigation in order to understand its origin. Overall, the chemical composition of the cyst walls may also allow for species discrimination (chemotaxonomy), which is supported by morphology-based taxonomy and molecular phylogeny.

\section{Acknowledgements}

We thank Raymond Below and Michael Amler (Köln University) for permission to study the Benedek collection of Oligocene cyst holotypes. Chris Reid and Charles Wellman (Sheffield University) are thanked for permission to access the Reid holotype collection and we are grateful to Prof. He Chengquan for permission to reproduce his holotype images. The Regional Council of Brittany, the General Council of Finistère and the urban community of Concarneau-Cornouaille-Agglomération are acknowledged for the funding of the Sigma 300 FE-SEM of the station of Marine Biology in Concarneau. Kara Bogus acknowledges support from the National Science Foundation (OCE-1326927). The Research Foundation Flanders (FWO, Hercules Foundation) is thanked for funding the micro-FTIR facility (FT-IMAGER, project number AUGE/13/16). Ocean Networks Canada (ONC), Audrey Dallimore (Royal Roads University) and students of EOS313 (SEOS, University of Victoria) are all thanked for their contribution in sediment sample collection. Vera Pospelova acknowledges support from 
a Discovery Grant (RGPIN/6388-2015) of the Natural Sciences and Engineering Research Council of Canada (NSERC).

\section{References}

Abé TH. 1981. Studies on the family Peridiniales. Publ Seto Mar Biol Lab, Spec Publ Ser 6:1-409.

Artzner DG, Dörhöfer G. 1978. Taxonomic note: Lejeunecysta nom. nov. pro. Lejeunia Gerlach 1961 emend. Lentin and Williams 1976 - dinoflagellate cyst genus. Can J Bot 56:1381-1382.

Attaran-Fariman G, Khodami S, Bolch CJS. 2011. The cyst-motile relationship of three Protoperidinium species from south-east coast of Iran. Iran J Fish Sci 10, 1-12.

Balech E. 1974. El Genero 'Protoperidinium' Bergh, 1881 (Peridinium Ehrenberg, 1831, partim). Rev Mus Arg Cs Nat’B Rivadavia”, Hidrobiol 4:1-79.

Benedek P. 1972. Phytoplanktonten aus dem Mittel- und Oberoligozän von Tönisberg (Niederrheingebiet). Palaeontographica B 137:1-71.

Blanco J. 1989. Quistes de Dinoflagelados de las costas de Galcia. II. Dinoflagelados Peridinioides. Sci Mar 53:797-812.

Boc A, Diallo AB, Makarenkov V, 2012. T-REX: a web server for inferring, validating and visualizing phylogenetic trees and networks. Nucleic Acids Res 40:W573-W579.

Bogus K, Mertens KNM, Lauwaert J, Harding IC, Vrielinck H, Zonneveld KAF, Versteegh GJM. 2014. Differences in the chemical composition of organic-walled dinoflagellate resting cysts from phototrophic and heterotrophic dinoflagellates. J Phycol 50:254-266.

Bruker. 2014. OPUS Spectroscopy Software User Manual. Bruker Optik GmbH, Ettlingen.

Bujak JP, Downie C, Eaton GL, Williams GL. 1980. Dinoflagellate cysts and acritarchs from the Eocene of southern England. Spec. Pap. Palaeontol. 24:1-100. 
Bujak JP, Davies EH. 1983. Modern and fossil Peridiniineae. AASP Contr Ser 13:1-203 + 12 pl.

Bujak JP, Williams GL. 1981. The evolution of dinoflagellates. Can J Bot 59, 2077-2087.

Cárdenas G, Cabrera G, Taboada E, Miranda SP. 2004. Chitin characterization by SEM, FTIR, XRD, and ${ }^{13} \mathrm{C}$ cross polarization/mass angle spinning NMR. J Appl Polym Sci 93:1876-1885.

Colthup NB, Daly LH, Wiberley SE. 1990. Introduction to Infrared and Raman Spectroscopy, $3^{\text {rd }}$ ed., Academic Press, San Diego, 547 pp.

Daugbjerg N, Hansen G, Larsen J Moestrup Ø. 2000. Phylogeny of some of the major genera of dinoflagellates based on ultrastructure and partial LSU rDNA sequence data, including the erection of three new genera of unarmoured dinoflagellates. Phycologia 39:302-317.

De Schepper S, Gibbard PL, Salzmann U, Ehlers J. 2014. A global synthesis of the marine and terrestrial evidence for glaciation during the Pliocene Epoch. Earth Sci Rev 135:83102.

de Verteuil L, Norris G. 1992. Miocene protoperidiniacean dinoflagellate cysts from the Maryland and Virginia coastal Plain. In: Head MJ, Wrenn JH (Eds.) Neogene and Quaternary Dinoflagellate Cysts and Acritarchs. American Association for Stratigraphic Palynologists Foundation, Dallas, 391-430.

Ellegaard M, Head MJ, Versteegh GJM. 2018. Linking biological and geological data on dinoflagellates using the genus Spiniferites as an example: the implications of species concepts, taxonomy and dual nomenclature. Palynology 42(S1):221-230.

Faust MA. 2006. Creation of the subgenus Testeria Faust subgen. nov. Protoperidinium Bergh from the SW Atlantic Ocean: Protoperidinium novella sp. nov. and Protoperidinium concinna sp. nov. Dinophyceae. Phycologia 45:1-9. 
Gerlach E. 1961. Mikrofossilien aus dem Oligozän und Miozän Nordwestdeutschlands, unter besonderer Berücksichtigung der Hystrichosphaeren und Dinoflagellaten. N Jb Paläont Abh 112, 2:143-228.

Gribble KE, Anderson DM. 2006. Molecular phylogeny of the heterotrophic dinoflagellates, Protoperidinium, Diplopsalis and Preperidinium (Dinophyceae), inferred from large subunit rDNA. Journal of Phycology 42, 1081-1095.

Gribble KE, Anderson DM, Coates DW. 2009 Sexual and Asexual Processes in Protoperidinium steidingerae Balech (Dinophyceae), with Observations on Life-History Stages of Protoperidinium depressum (Bailey) Balech (Dinophyceae). J Eukaryot. Microbiol. 56:88-103.

Gu H, Liu T, Mertens KN. 2015. Cyst-theca relationship and phylogenetic positions of Protoperidinium (Peridiniales, Dinophyceae) species of the sections Conica and Tabulata, with description of Protoperidinium shanghaiense sp. nov. Phycologia 54:4966.

Guillard RRL, Ryther JH. 1962. Studies of marine planktonic diatoms. I. Cyclotella nana Hustedt and Detonula confervacea Cleve. Can J Microbiol 8:229-239.

Gurdebeke PR, Mertens KN, Pospelova V, Van Riet B, Li Z, Dallimore A, Louwye S. 2017. A new centennial scale Late Quaternary dinoflagellate cyst record from Vancouver Island (British Columbia, Canada). DINO11, Bordeaux, July 17-21, 2017.

Gurdebeke PR, Mertens KN, Bogus K, Marret F, Chomérat N, Vrielinck H, Louwye S. 2018a. Taxonomic re-investigation and geochemical characterization of Reid's (1974) species of Spiniferites from holotype and topotype material. Palynology. DOI:10.1080/01916122.2018.1465735. 
Gurdebeke PR, Pospelova V, Mertens KN, Dallimore A, Chana J, Louwye S. 2018b. Diversity and distribution of dinoflagellate cysts in surface sediments from fjords of western Vancouver Island (British Columbia, Canada). Mar Micropaleontol 143:12-29.

Gurdebeke PR, Pospelova V, Mertens KN, Li Z, Van Riet B, Dallimore A, Louwye S. Holocene environmental history of NW Vancouver Island (British Columbia, Canada) based on a high resolution dinoflagellate cyst record from the Kyuquot Sound. Paper in preparation.

Hall TA. 1999. BioEdit: a user-friendly biological sequence alignment editor and analysis program for Windows 95/98/NT. pp. 95-98

Hammer O, Harper DAT, Ryan PD. 2001. PAST: Paleontological statistics software package for education and data analysis. Palaeontol Electron 4, 9 pp.

Harland R. 1977. Recent and late Quaternary (Flandrian and Devensian) dinoflagellate cysts from marine continental shelf sediments around the British Isles. Palaeontographica B 164:87-126.

Harland R. 1982. A review of recent and Quaternary organic-walled dinoflagellate cysts of the genus Protoperidinium. Palaeontology 25:369-397.

He C, Sun X. 1991. Dinoflagellate cysts from Quaternary sediments of Nansha, the South China Sea. In: The Multidisciplinary Oceanographic Expedition Team of Academia Sinica to the Nansha Islands (eds.), Quaternary Biological Groups of the Nansha Islands and the Neighbouring Waters, pp. 266-302, 520-525; Science Press, Beijing, China.

Head MJ. 1993. Dinoflagellates, Sporomorphs, and Other Palynomorphs from the Upper Pliocene St. Erth Beds of Cornwall, Southwestern England. Palaeontol Soc Memoir 31:1-62. 
Head MJ. 1996. Chapter 30. Modern dinoflagellate cysts and their biological affinities. In: Jansonius J, McGregor DC (eds.), Palynology: principles and applications. Vol. 3 American Association of Stratigraphic Palynologists Foundation, Vol. 3, 1197-1248.

Head MJ, Fensome RA, Herendeen PS, Skog JE. 2016. Proposals to ament Article 11.8 and its Examples to remove ambiguity in the sanctioning of dual nomenclature for dinoflagellates, and an emendation of Article 11.7, Example 29. Taxon 65:902-903.

Jacobson DM, Anderson DM. 1986. Thecate heterotrophic dinoflagellates: feeding behavior and mechanisms. J Phycol 22:249-258.Jardine PE, Abernethy FAJ, Lomax BH, Gosling WD, Fraser WT. 2015. Shedding light on sporopollenin chemistry, with reference to UV reconstruction. Rev Palaeobot Palynol 238:1-6.

Jörgensen E. 1912. Bericht über die von der schwedischen hydrographisch-biologischen Kommission in den schwedischen Gewässern in den Jahren 1909-1910 eingesammelten Planktonproben. Svenska Hydrogr-Biol Komm Skr 4:1-20.

Julier ACM, Jardine PE, Coe AL, Gosling WD, Lomax BH, Fraser WT. 2016. Chemotaxonomy as a tool for interpreting the cryptic diversity of Poaceae pollen. Rev Palaeobot Palynol 235:140-147.

Jurkschat T. 2003. Paläoproduktivitäts-Schwankungen und Veränderungen der paläozeanographischen Bedingungen im Arabischen Meer während der letzten 130.000 Jahre -rekonstruiert anhand von organischen Dinoflagellatenzysten. PhD-thesis, Hannover University.

Katoh K, Standley DM. 2013. MAFFT multiple sequence alignment software version 7: improvements in performance and usability. Mol Biol Evol 30:772-780.

Kawamura H. 2004. Dinoflagellate cyst distribution along a shelf to slope transect of an oligotrophic tropical sea (Sunda Shelf, South China Sea). Phycol Res 52:355-375. 
Kjellström G. 1972. Archaeopyle formation in the genus Lejeunia Gerlach, 1961 emend. Geologiska Föreningens i Stockholm Förhandlingar 94:467-469.

Krepakevich A, Pospelova V. 2010. Tracing the influence of sewage discharge on coastal bays of Southern Vancouver Island (BC, Canada) using sedimentary records of phytoplankton. Cont Shelf Res 30:1924-1940.

Lentin JK, Williams GL. 1976. A monograph of fossil peridinioid dinoflagellate cysts. Bedford Institute of Oceanography, Report Series, BI-R-75-16, 237 pp.

Lentin JK, Williams GL. 1993. Fossil dinoflagellates: index to genera and species. American Association of Stratigraphic Palynologists, Contributions Series 28, $856+$ viii p.

Lewituss E, Bittner L, Malviya S, Bowler C, Morlon H. 2018. Clade-specific diversification dynamics of marine diatoms since the Jurassic. Nat Ecol Evol 2:1715-1723.

Li Z, Pospelova V, Liu L, Zhou R, Song B. 2017. High-resolution palynological record of Holocene climatic and oceanographic changes in the northern South China Sea. Palaeogeogr Palaeoclimatol Palaeoecol 483:97-124

Li Z, Pospelova V, Lin HL, Liu L, Song B, Gong W. 2018. Seasonal dinoflagellate cyst production and terrestrial palynomorphs deposition in the East Asian Monsoon influenced South China Sea: A sediment trap study from the Southwest Taiwan waters. Rev Palaeobot Palynol 257:117-139.

Li Z, Pospelova V, Luo C, Hernandez-Almeida I, Mertens KN, Yin K, Wu Y, Wu H (in prep.). Dinoflagellate cyst distribution in surface sediments from the South China Sea in relation to hydrological conditions and primary productivity. Quaternary Res.

Li Z, Mertens KN, Pospelova V, Gu H, Matsuoka K, Liu L, Li C (in prep.). An ultrastructural study of dinoflagellate cysts belonging to Spiniferites and Achomosphaera occurring in Holocene sediments of the Asian Pacific. Rev Palaeobot Palynol.Lisiecki LE, Raymo 
ME. 2007. Plio-Pleistocene climate evolution: trends and transitions in glacial cycle dynamics. Quat Sci Rev 26:56-69.

Londeix L, Jan Du Chêne R. 1998. Burdigalian dinocyst stratigraphy of the stratotypic area (Bordeaux, France). Geobios 30:283-294.

Louwye S, Head MJ, De Schepper S. 2004. Dinoflagellate cyst stratigraphy and palaeoecology of the Pliocene in northern Belgium, southern North Sea Basin. Geol Mag 141:353-378.

Luo Z, Krock B, Mertens KN, Nézan E, Chomérat N, Bilien G, Tillmann U, Gu H. 2017. Adding new pieces to the Azadinium (Dinophycheae) diversity and biogeography puzzle: Non-toxigenic Azadinium zhuanum sp. nov. from China, toxigenic A. poporum from the Mediterranean, and a non-toxigenic A. dalianense from the French Atlantic. Harmful Algae 66:65-78.

Luo Z, Lim ZF, Mertens KN, Gurdebeke PR, Bogus K, Carbonell-Moore MC, Vrielinck H, Leaw CP, Lim PT, Chomérat N, Li X, Gu H. 2018. Morpho-molecular diversity and phylogeny of Bysmatrum (Dinophyceae) from the South China Sea and France. Eur J Phycol 53:318-335.

Matsuoka K. 1987. Organic-walled dinoflagellate cysts from surface sediments of Akkeshi Bay and Lake Saroma, North Japan. Bull Fac Lib Arts of Nagasaki Univ (Nat Sci) 28:35-123.

Matsuoka K. 1992. Species diversity of modern dinoflagellate cysts in surface sediments around the Japanese Islands. In. Head, M. J. and Wrenn, J. H. (Eds.) Neogene and Quaternary Dinoflagellate Cysts and Acritarchs. American Association for Stratigraphic Palynologists Foundation, Dallas, 33-53.

Matsuoka K. 2002. Implications of cyst morphology to dinoflagellate cyst taxonomy. Fish Sci 68:507-510. 
Matsuoka K, Head MJ. 2013. Clarifying cyst-motile stage relationships in dinoflagellates. In: Lewis, J.M., Marret, F., Bradley, L. (eds.), Biological and Geological Perspectives of Dinoflagellates. The Micropaleontological Society Special Publication, London, 325350.

Matsuoka K, Kawami H. 2013. Phylogenetic subdivision of the genus Protoperidinium (Peridiniales, Dinophyceae) with emphasis on the Monovela Group. In: Lewis, J.M., Marret, F., Bradley, L. (Eds.), Biological and Geological Perspectives of Dinoflagellates. The Micropaleontological Society Special Publication, London, 275283.

Matsuoka K, Kawami H, Fujii R, Iwataki M. 2006. Further examination of the cyst-theca relationship of Protoperidinium thulesense (Peridiniales, Dinophyceae) and the phylogenetic significance of round brown cysts. Phycologia 45:632-641.

McMinn A. 1991. Recent Dinoflagellate Cysts from Estuaries on the Central Coast of New South Wales, Australia. Micropaleontology 37:269-287.

Mertens KN, Ribeiro S, Bouimetarhan I, Caner H, Combourieu-Nebout N, Dale B, de Vernal A, Ellegaard M, Filipova M, Godhe A, et al. 2009. Process length variation in cysts of a dinoflagellate, Lingulodinium machaerophorum, in surface sediments: investigating its potential as salinity proxy. Mar Micropal 70:54-69.

Mertens KN, Price AM, Pospelova V. 2012. Determining the absolute abundance of dinoflagellate cysts in recent marine sediments II: Further tests of the Lycopodium marker-grain method. Rev Palaeobot Palynol 184:74-81.

Mertens KN, Aydin H, Uzar S, Takano Y, Yamaguchi A, Matsuoka J. 2015. Relationship between the dinoflagellate cyst Spiniferites pachydermus and Gonyaulax ellegaardiae sp. nov. from Izmir Bay, Turkey, and molecular characterization. J Phycol 51:560-573. 
Mertens KN, Takano Y, Gu H, Bagheri S, Pospelova V, Pienkowski AJ, Leroy S, Matsuoka K. 2017a. Cyst-Theca Relationship and Phylogenetic Position of Impagidinium caspienense Incubated from Caspian Sea Surface Sediments: Relation to Gonyaulax baltica and Evidence for Heterospory within Gonyaulacoid Dinoflagellates. J Eukaryot Microbiol 64:829-842.

Mertens KN, Gu H, Pospelova V, Chomérat N, Nézan E, Gurdebeke PR, Bogus K, Vrielinck H, Rumebe M, Meteigner C. 2017b. First record of resting cysts of the benthic dinoflagellate Prorocentrum leve in a natural reservoir in Gujan-Mestras, Gironde, France. J Phycol 53:1193-1205.

Mertens KN, Gu H, Takano Y, Price AM, Pospelova V, Bogus K, Versteegh GJM, Marret F, Turner RE, Rabalais NN, Matsuoka K. 2017c The cyst-theca relation of Trinovantedinium pallidifulvum, with erection of Protoperidinium lousianensis sp. nov. and their phylogenetic position within the Conica group. Palynology.

Narale DD, Patil JS, Anil AC. 2013. Dinoflagellate cyst distribution in recent sediments along the south-east coast of India. Oceanologia 55:979-1003.

Phan-Tan L, Nguyen-Ngoc L, Doan-Nhu D, Raine R, Larsen J. 2017. Species diversity of Protoperidinium sect. Oceanica (Dinophyceae, Peridiniales) in Vietnamese waters, with description of the new species P. larsenii sp. nov. Nord J Bot 35:129-146.

Posada D, 2008. jModelTest: phylogenetic model averaging. Mol Biol Evol 25:1253-1256.

Pospelova V, Chmura GL, Boothman WS, Latimer JS. 2005. Spatial distribution of modern dinoflagellate cysts in polluted estuarine sediments from Buzzards Bay (Massachusetts, USA) embayments. Mar Ecol Prog Ser 292:23-40.

Prasad V, Garg R, Singh V, Thakur B. 2007. Organic matter distribution pattern in Arabian Sea: Palynofacies analysis from the surface sediments off Karwar coast (west coast of India). Indian J Mar Sci 36:399-406. 
Price AM, Pospelova V. 2011. High-resolution sediment trap study of organic-walled dinoflagellate cyst production and biogenic silica flux in Saanich Inlet (BC, Canada). Mar Micropaleontol 80:18-43

Price AM, Gurdebeke PR, Mertens KN, Pospelova V. 2016. Determining the absolute abundance of dinoflagellate cysts in recent marine sediments III: Identifying the source of Lycopodium loss during palynological processing and further testing of the Lycopodium marker-grain method. Rev Palaeobot Palynol. 226:78-90.

Reid PC. 1972. The distribution of dinoflagellate cysts, acritarchs and pollen in coastal sediments from the British Isles. Unpublished PhD thesis, University of Sheffield.

Reid PC. 1977. Peridiniacean and glenodiniacean dinoflagellate cysts from the British Isles. Nova Hedwigia 29:429-463.

Riding JB, Pound MJ, Hill TCB, Stukins S, Feist-Burkhardt S. 2012. The John Williams Index of Palaeopalynology. Palynology 36:224-234.

Ronquist F, Huelsenbeck JP. 2003. MrBayes 3: Bayesian phylogenetic inference under mixed models. Bioinformatics 19:1572-1574.

Sarai C, Yamaguchi A, Kawami H, Matsuoka K. 2013. Two new species formally [sic] attributed to Protoperidinium oblongum (Aurivillius) Park [sic] et Dodge (Peridiniales, Dinophyceae): Evidence from cyst incubation experiments. Rev Palaeobot Palynol 192:103-118.

Scholin CA, Herzog M, Sogin M, Anderson DM. 1994. Identification of group- and strainspecific genetic markers for globally distributed Alexandrium (Dinophyceae). II. Sequence analysis of a fragment of the LSU rRNA gene. J Phycol 30:999-1011.

Sherr EB, Sherr BF. 2007. Heterotrophic dinoflagellates: a significant component of microzooplankton biomass and major grazers of diatoms in the sea. Mar Ecol Prog Ser 352:187-197.Stamatakis A. 2006. RAxML-VI-HPC: maximum likelihood-based 
phylogenetic analyses with thousands of taxa and mixed models. Bioinformatics $22: 2688-2690$.

Stover LE, Evitt WB. 1978. Analyses of Pre-Pleistocene organic-walled dinoflagellates. Stanford University Publications, Geological Sciences 15, 300 pp.

Taylor FJR. 1976. Dinoflagellates from the International Indian Ocean Expedition. A report on material collected by the R.V. "Anton Bruun" 1963-1967. Bibliotheca Botanica 132, $234 \mathrm{pp}$.

Versteegh GJM, Blokker P, Bogus K, Harding IC, Lewis J, Oltmanns S, Rochon A, Zonneveld KAF. 2012. Flash pyrolysis and infrared spectroscopy of cultured and sediment derived Lingulodinium polyedrum (Dinoflagellata) cyst walls. Org Geochem 43:92-102.

Wall D, Dale B. 1968. Modern dinoflagellate cysts and evolution of the Peridiniales. Micropaleontology 14:265-304.

Watson JS, Sephton MA, Sephton SV, Self S, Fraser WT, Lomax BH, Gilmour I, Wellman CH, Beerling DJ. 2007. Rapid determination of spore chemistry using thermochemolysis gas chromatography-mass spectrometry and micro-Fourier transform infrared spectroscopy. Photoch Photobio Sci 6:689-694.

Williams GL, Bujak J. 1977. Cenozoic palynostratigraphy of offshore eastern Canada. AASP Contribution Series 5A:14-47.

Williams GL, Fensome RA, MacRae RA. 2017. The Lentin and Williams index of fossil dinoflagellates 2017 edition. American Association of Stratigraphic Palynologists Contributions Series, no. 48, 1097 pp.

Yamaguchi A, Kawamura H, Horiguchi T. 2006. A further phylogenetic study of the heterotrophic dinoflagellate genus, Protoperidinium (Dinophyceae) based on small and large subunit ribosomal RNA gene sequences. Phycol Res 54:317-329. 
Zonneveld KAF, Marret F, Versteegh GJM, Bonnet S, Bouimetarhan I, Crouch E, de Vernal A, Elshanawany R, Edwards L, Esper O, Forke S, Grøsfjeld K, Henry M, Holzwarth U, Kielt J-F, Kim SY, Ladouceur S, Ledu D, Chen L, Limoges A, Londeix L, Lu SH, Mahmoud MS, Marino G, Matsouka [sic] K, Matthiessen J, Mildenhal [sic] DC, Mudie P, Neil HL, Pospelova V, Qi Y, Radi T, Richerol T, Rochon A, Sangiorgi F, Solignac S, Turon JL, Verleye T, Wang Y, Wang Z, Young M. 2013. Atlas of modern dinoflagellate cyst distribution based on 2405 datapoints. Rev Palaeobot Palynol 191:1-197. 
Table 1. Generic characteristics of peridinioid dinoflagellate cysts that are bilaterally symmetrical, pentagonal and have one apical and two antapical horns.

\begin{tabular}{|c|c|c|c|c|}
\hline Genus & Votadinium & Lejeunecysta & Quinquecuspis & Trinovantedinium \\
\hline \multicolumn{5}{|l|}{ Appearance } \\
\hline General shape & Dorsoventrally compressed, pentagonal to rounded. & $\begin{array}{l}\text { Peridinioid with dorsoventral compression and a } \\
\text { pentagonal ambitus. Epi- and hypocyst of } \\
\text { approximately equal length }\end{array}$ & Pentagonal, peridinioid, acavate. & $\begin{array}{l}\text { Proximochorate, protoperidiniacean, pentagonal to } \\
\text { subcircular, dorsoventrally compressed. }\end{array}$ \\
\hline Tabulation & Not expressed & $\begin{array}{l}\text { Only indicated near the archeopyle and } \\
\text { paracingulum. }\end{array}$ & Absent & $\begin{array}{l}\text { Dorsally reflected by archeopyle, ventrally } \\
\text { variable. }\end{array}$ \\
\hline Wall structure & Smooth or microgranular single wall & chagrinate. & Autophragm, acavate, thickens at apex and antapex & $\begin{array}{l}\text { Biphragmal, with or without pericoels, usually } \\
\text { closely adpressed; pericoel development not } \\
\text { pronounced or spectacular. The surface of the } \\
\text { phragma may be psilate or carry a simple } \\
\text { ornament, but it does not possess any reticulum. }\end{array}$ \\
\hline Wall thickness & Thin wall & Thin wall & Thick wall & - \\
\hline Ornamentation & $\begin{array}{l}\text { None, small processe } \\
\text { ornamentation. }\end{array}$ & None & None & $\begin{array}{l}\text { Surface variably covered by short, penitabular and } \\
\text { intratabular, but never sutural , solid or hollow } \\
\text { spines or processes. Hollow processes may be } \\
\text { distally open or closed }\end{array}$ \\
\hline Paracingulum & No indentation, at most absence of ornamentation & $\begin{array}{l}\text { A planar or very slightly helicoidal paracingulum is } \\
\text { delimited by two folds and a shallow indentation. } \\
\text { The folds are distally entire and may be continuous } \\
\text { or partite. When partite, the paracingulum is } \\
\text { separated into seven anterior and five posterior } \\
\text { divisions. }\end{array}$ & $\begin{array}{l}\text { Conspicuous and planar, usually delimited by low } \\
\text { ridges }\end{array}$ & Well to poorly defined \\
\hline Parasulcus & Absent to expressed as shallow depression & Marked by a shallow depression. & $\begin{array}{l}\text { Very deeply indented, with reflection of flagellar } \\
\text { pores }\end{array}$ & Well to poorly defined \\
\hline $\begin{array}{l}\text { Epicystal } \\
\text { characters }\end{array}$ & Rounded apex or elongated apical horn. & $\begin{array}{l}\text { Apex rounded or prolonged into a small distinct } \\
\text { boss. }\end{array}$ & Conical or with shoulder & $\begin{array}{l}\text { Lateral sides convex or straight, apex rounded or } \\
\text { angular with or without apical horn or boss. }\end{array}$ \\
\hline $\begin{array}{l}\text { Hypocystal } \\
\text { characters }\end{array}$ & $\begin{array}{l}\text { Rounded broad or elongated antapical horns } \\
\text { separated by a shallow or deep concavity. }\end{array}$ & $\begin{array}{l}\text { Two approximately equal, symmetrically located } \\
\text { horns which are small, pointed and solid. }\end{array}$ & Symmetrical horns or flat antapically & Antapical horns symmetrical or asymmetrical \\
\hline Archeopyle & $\begin{array}{l}\text { Intercalary } 1 \mathrm{a} \text { or } 2 \mathrm{a} \text {, dorsal or involving apical } \\
\text { section. Hexagonal or rounded. }\end{array}$ & $\begin{array}{l}\text { Intercalary 2a and is symmetrically located on the } \\
\text { middorsal line. It extends almost to the } \\
\text { paracingulum. Operculum free or attached along } \\
\text { the posterior margin. }\end{array}$ & $\begin{array}{l}\text { Basically intercalary, } ? 2 \text { a, but may also involve } \\
\text { apical plate } ? 3^{\prime}\end{array}$ & $\begin{array}{l}\text { Simple hexa } 2 \text { a intercalary archeopyle, operculum } \\
\text { free. }\end{array}$ \\
\hline Reference & Reid (1977); this paper & Bujak et al. (1980) & Harland (1977) & de Verteuil \& Norris (1992) \\
\hline
\end{tabular}

$*$ Defined in this paper. 
Table 2. Location, coordinates, sample nature and references to literature for samples used in this study.

\begin{tabular}{|c|c|c|c|c|c|}
\hline Sample ID & Locality & Latitude & Longitude & Sample nature & Reference(s) \\
\hline \multicolumn{6}{|c|}{ Samples for taxonomy - LM } \\
\hline UVic 2008-5-1 & off Albert Head, near Metchosin, Strait of Juan de Fuca & $48^{\circ} 23.2266^{\prime} \mathrm{N}$ & $123^{\circ} 28.214^{\prime} \mathrm{W}$ & Palynological slide, surface sediment & Krepakevich and Pospelova (2010) \\
\hline UVic 2009-179-1 & Patricia Bay, Saanich Inlet & $48^{\circ} 39.997 ' \mathrm{~N}$ & $123^{\circ} 29.014^{\prime} \mathrm{W}$ & Palynological slide, core sediment & Price and Pospelova (2011) \\
\hline UVic 2009-408-1 & Patricia Bay, Saanich Inlet & $48^{\circ} 39.997^{\prime} \mathrm{N}$ & $123^{\circ} 29.014^{\prime} \mathrm{W}$ & Palynological slide, sediment trap & Price and Pospelova (2011) \\
\hline UVic 2012-197-1 & Patricia Bay, Saanich Inlet & $48^{\circ} 39.005^{\prime} \mathrm{N}$ & $123^{\circ} 29.027^{\prime} \mathrm{W}$ & Palynological slide, surface sediment & Mertens et al. (2012) \\
\hline UVic 2013-326-1 & Patricia Bay, Saanich Inlet & $48^{\circ} 35.554^{\prime} \mathrm{N}$ & $123^{\circ} 30.034^{\prime} \mathrm{W}$ & Palynological slide, surface sediment & Price et al. (2016) \\
\hline UVic 2015-622-2 & Kyuquot Sound & $50^{\circ} 05.463^{\prime} \mathrm{N}$ & $127^{\circ} 09.046^{\prime} \mathrm{W}$ & Palynological slide, core sediment & Gurdebeke et al. (in prep.) \\
\hline UVic 2015-684-2 & Kyuquot Sound & $50^{\circ} 05.463^{\prime} \mathrm{N}$ & $127^{\circ} 09.046^{\prime} \mathrm{W}$ & Palynological slide, core top & Gurdebeke et al. (in prep.) \\
\hline UVic 2014-112 & South China Sea & $20^{\circ} 01.965^{\prime} \mathrm{N}$ & $115^{\circ} 27.882^{\prime} \mathrm{E}$ & Palynological slide, core sediment & Li et al. (2017) \\
\hline UVic 2014-149 & South China Sea & $20^{\circ} 01.965^{\prime} \mathrm{N}$ & $115^{\circ} 27.882^{\prime} \mathrm{E}$ & Palynological slide, core sediment & Li et al. (2017) \\
\hline UVic 2015-287 & South China Sea & $22^{\circ} 39.817^{\prime} \mathrm{N}$ & $119^{\circ} 55.342^{\prime} \mathrm{E}$ & Palynological slide, sediment trap & Li et al. (2018) \\
\hline UVic 2017-11 & South China Sea & $18^{\circ} 38.210^{\prime} \mathrm{N}$ & $111^{\circ} 14.480^{\prime} \mathrm{E}$ & Palynological slide, surface sediment & Li et al. (in prep.) \\
\hline WN142 & Bohai Sea & $39^{\circ} 55.864^{\prime} \mathrm{N}$ & $119^{\circ} 44.128^{\prime} \mathrm{E}$ & Culture experiment & Present study \\
\hline \multicolumn{6}{|c|}{ Samples for taxonomy - SEM } \\
\hline BV5 (SEM stub 16C6) & Vilaine estuary, Brittany, France & $47^{\circ} 30.152^{\prime} \mathrm{N}$ & $2^{\circ} 23.481^{\prime} \mathrm{W}$ & Residue for SEM, surface sediment & Mertens et al. (2009) \\
\hline MV0923-PO-1 & Vineyard Sound, Massachusetts & $41^{\circ} 19.500^{\prime} \mathrm{N}$ & $70^{\circ} 34.000^{\prime} \mathrm{W}$ & SEM mount from culture experiment & Gribble et al. (2009) \\
\hline WN142 & Bohai Sea & $39^{\circ} 55.864^{\prime} \mathrm{N}$ & $119^{\circ} 44.128^{\prime} \mathrm{E}$ & SEM mount from culture experiment & Present study \\
\hline UVic 2009-659 & Saanich Inlet & $48^{\circ} 33.148^{\prime} \mathrm{N}$ & $123^{\circ} 31.969^{\prime} \mathrm{W}$ & Residue for SEM, surface sediment & Price et al. (2016) \\
\hline SCS-FCG & Fangchanggang Port, South China Sea & $21^{\circ} 29.967^{\prime} \mathrm{N}$ & $108^{\circ} 13.883^{\prime} \mathrm{E}$ & Residue for SEM, surface sediment & Li et al. (in prep.) \\
\hline \multirow{2}{*}{\multicolumn{6}{|c|}{ Samples for micro-FTIR }} \\
\hline & & & & & \\
\hline UVic 2012-31 & Patricia Bay, Saanich Inlet & $48^{\circ} 39.150^{\prime} \mathrm{N}$ & $123^{\circ} 26.976^{\prime} \mathrm{W}$ & Residue for FTIR, surface sediment & This study \\
\hline IB St. 29 & Izmir Bay & $38^{\circ} 27.08^{\prime} \mathrm{N}$ & $27^{\circ} 08.28^{\prime} \mathrm{E}$ & Residue for FTIR, surface sediment & Mertens et al. (2015) \\
\hline Schillig & German Wadden Sea & $53^{\circ} 42.933^{\prime} \mathrm{N}$ & $7^{\circ} 58.199^{\prime} \mathrm{E}$ & Residue for FTIR, surface sediment & Bogus et al. (2014) \\
\hline UVic $16-320$ & Diana Lagoon, Corsica & $42^{\circ} 7.660^{\prime} \mathrm{N}$ & $9^{\circ} 31.720^{\prime} \mathrm{E}$ & Residue for FTIR, surface sediment & Luo et al. (2017) \\
\hline BV5, 16C6 & Vilaine estuary, Brittany, France & $47^{\circ} 30.152^{\prime} \mathrm{N}$ & $2^{\circ} 23.481^{\prime} \mathrm{W}$ & Residue for FTIR, surface sediment & Mertens et al. (2009) \\
\hline UVic 2015-684 & Kyuquot Sound & $50^{\circ} 05.463^{\prime} \mathrm{N}$ & $127^{\circ} 09.046^{\prime} \mathrm{W}$ & Residue for FTIR, core top sediment & Gurdebeke et al. (in prep) \\
\hline
\end{tabular}

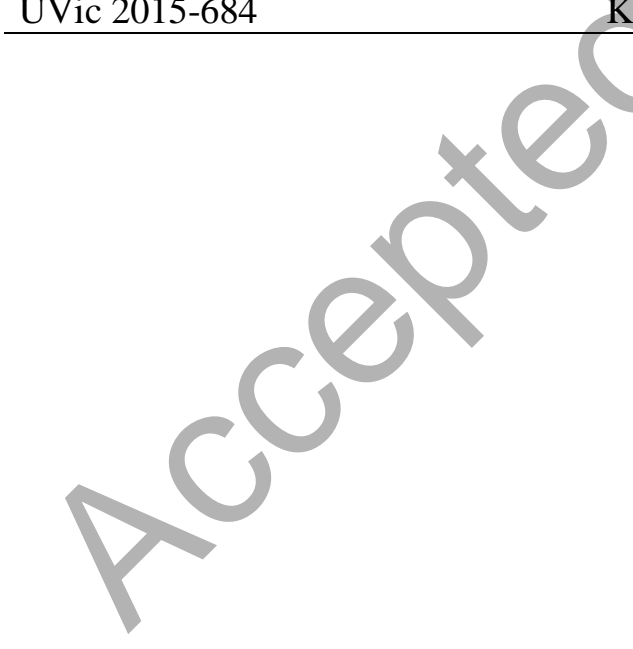


Table 3. Absorption peaks identified in the micro-FTIR spectra.

\begin{tabular}{ccc}
\hline Wave number $\left(\mathbf{c m}^{-1}\right)$ & Origin & Interpretation \\
\hline $3600-3000$ & $v \mathrm{OH}$ & Broad band \\
$3270-3100$ & $\nu \mathrm{NH}$ & \\
$2925-2860$ & $\nu \mathrm{CH}$ & \\
1660 & $\nu \mathrm{C}=\mathrm{O}$ & Amide I band \\
$1550-1570-1590$ & $\nu \mathrm{CN}+\delta \mathrm{NH}$ & Amide II band \\
$\mathbf{1 5 1 0}$ & $\mathrm{C}=\mathrm{C}$ & Aromatic ring \\
1420 & $\delta \mathrm{CH} 2$ & \\
1370 & $\delta \mathrm{CH}+\delta \mathrm{C}-\mathrm{CH} 3$ & \\
1312 & $\nu \mathrm{CN}+\delta \mathrm{NH}$ & Amide III band \\
1255 & $\delta \mathrm{NH}$ & \\
$\sim 1160$ & $\nu \mathrm{C}-\mathrm{O}-\mathrm{C}$ & Ring \\
$\sim 1113$ & $\nu \mathrm{C}-\mathrm{O}$ & Glucose ring \\
$\sim 1060$ & $\nu \mathrm{C}-\mathrm{O}$ & \\
$\sim 1030$ & $\nu \mathrm{C}-\mathrm{O}$ & \\
$\sim 900$ & $\gamma \mathrm{CH}$ & $\beta$-glycosidic bond \\
698 & $\gamma \mathrm{NH}$ & Amide $\mathrm{V}$ band \\
\hline
\end{tabular}




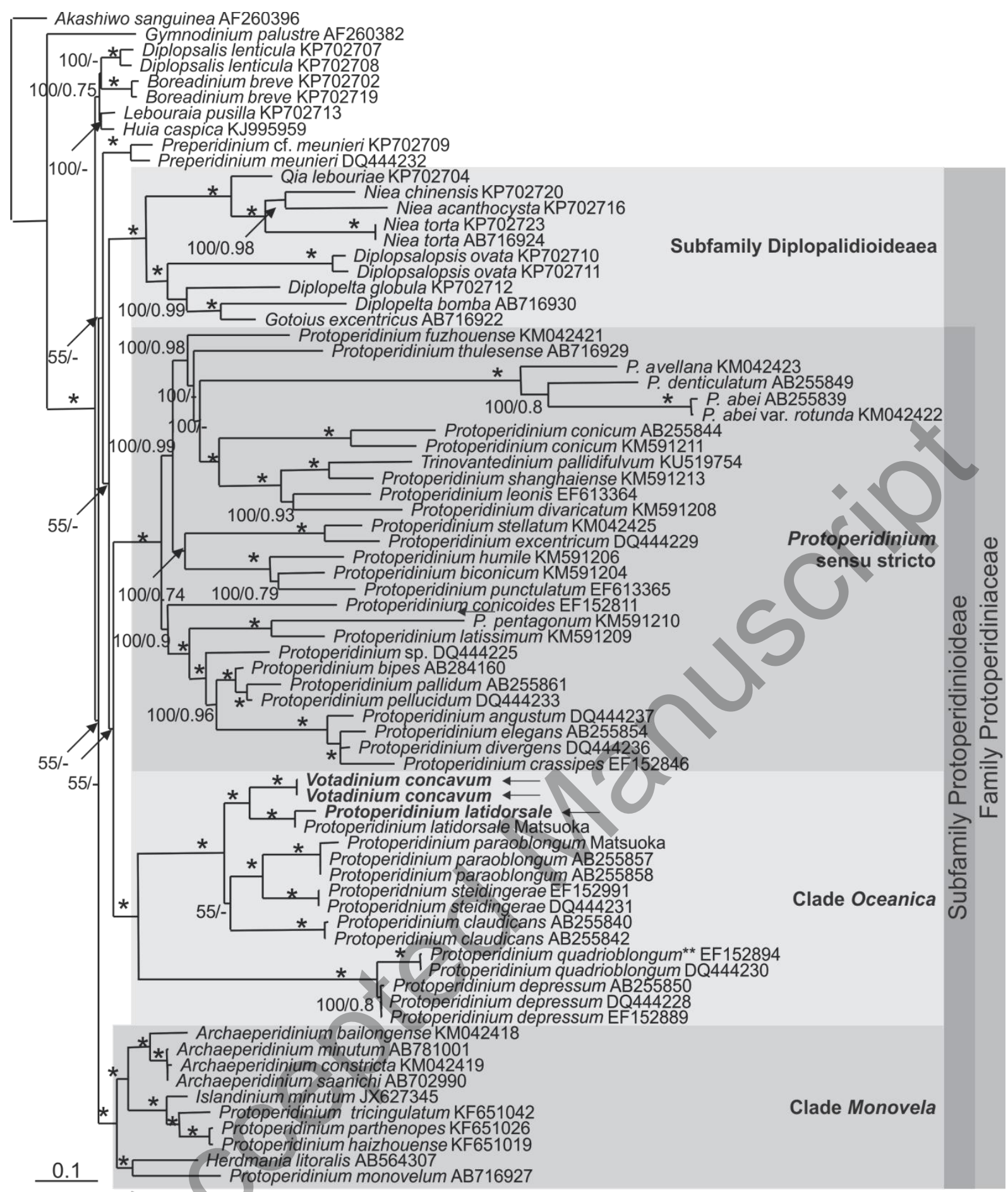

Fig. 1. LSU rDNA phylogenetic tree of the family Protoperidiniaceae, with the three new sequences for Votadinium concavum and Votadinium calvum shown in bold and indicated by arrows. Node numbers indicate bootstrap support values (1000 replicates), * means these nodes are found in all replicates. [Genbank to be inserted in proof] 


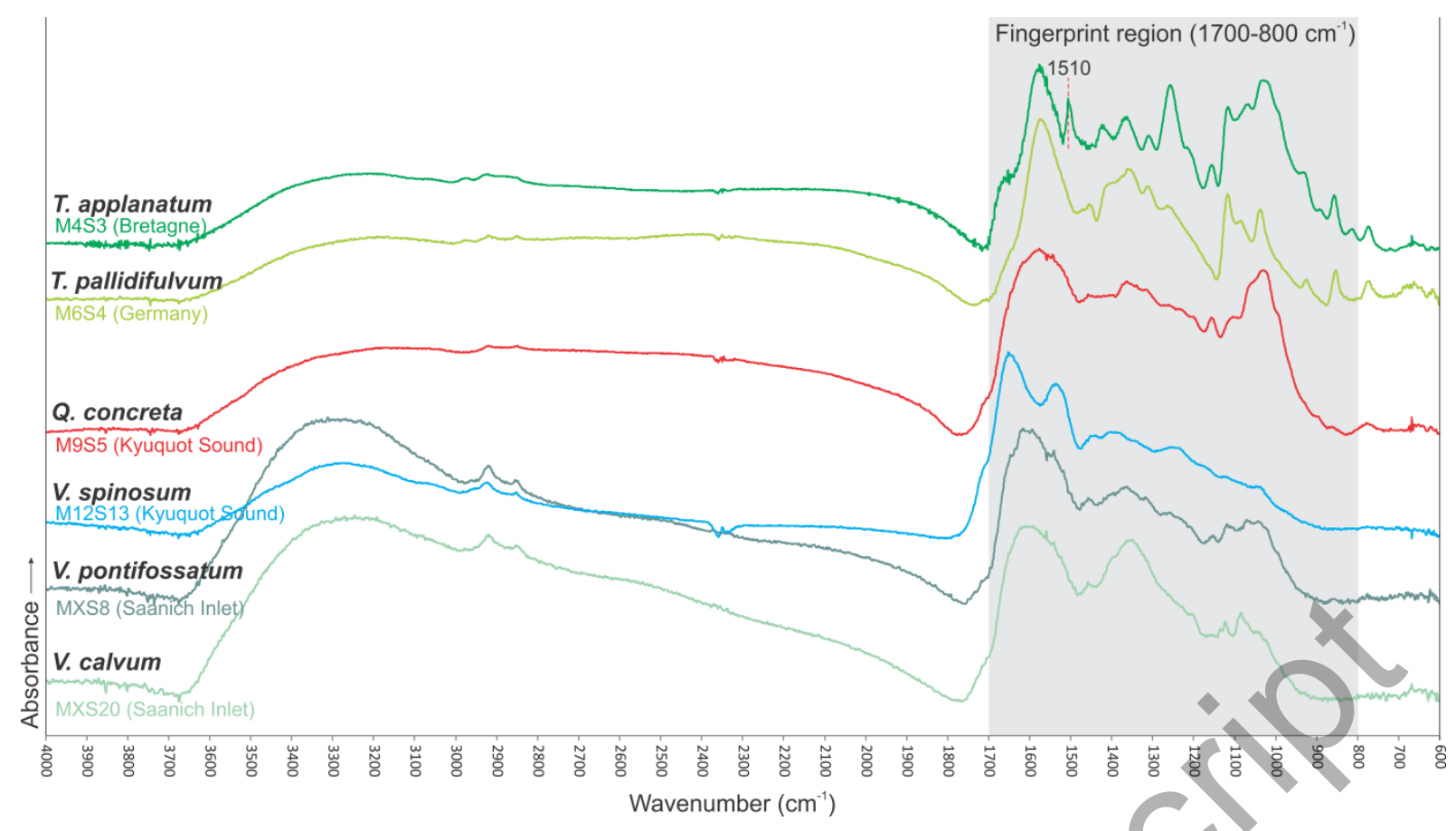

Fig. 2. Representative FTIR spectra of Trinovantedinium applanatum, T. pallidifulvum, Quinquecuspis concreta, Votadinium spinosum, V. pontifossatum, V. calvum. Grey shading indicates the fingerprint region (1700-800 $\mathrm{cm}^{-1}$ ) comprising the data used for the PCA analysis (see Fig. 3). See Table 3 for explanation of the absorption peaks. 


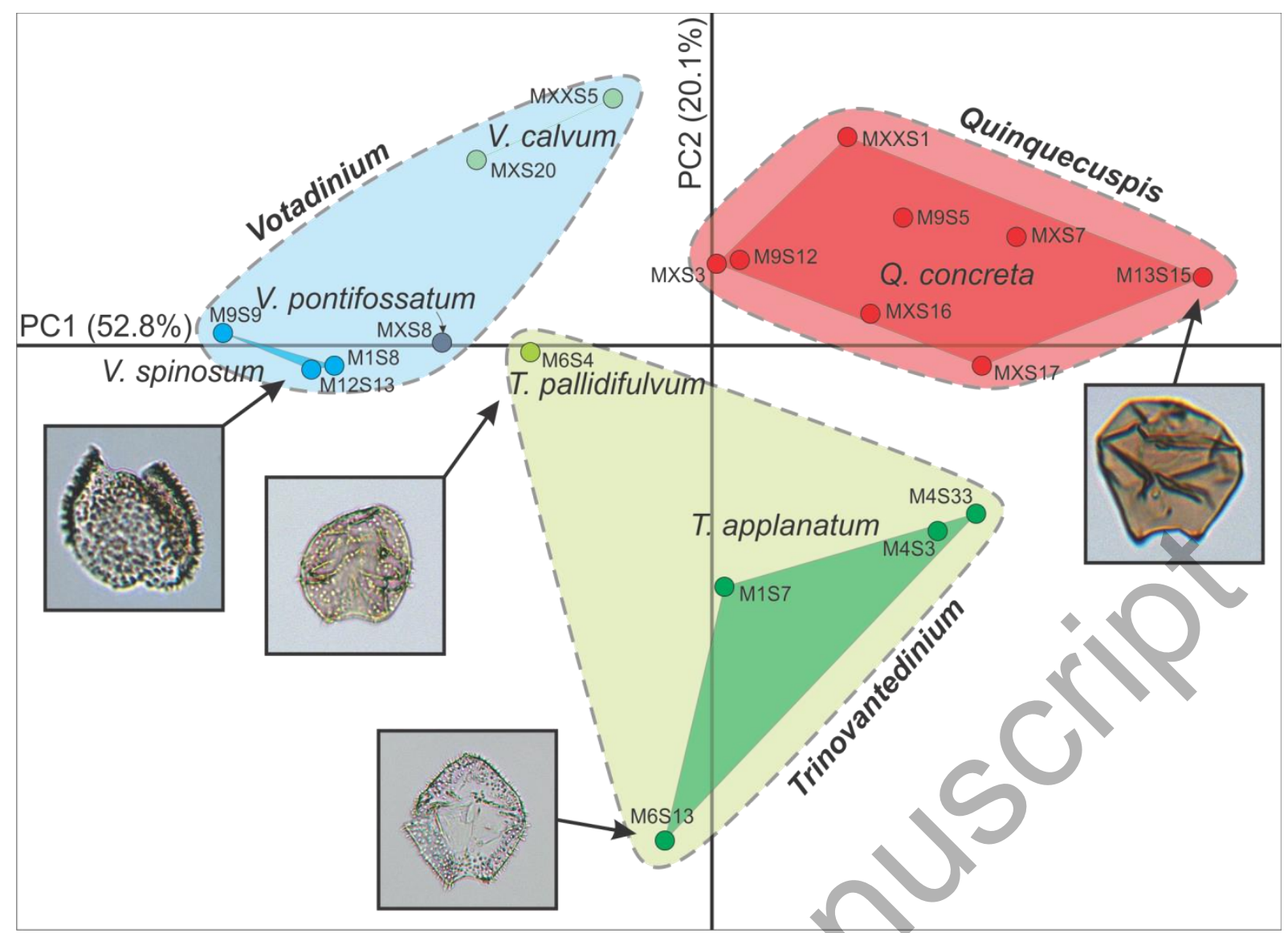

Fig. 3. Ordination plot of principal components PC1 and PC2 of FTIR spectral data in the fingerprint range (1700-800 $\left.\mathrm{cm}^{-1}\right)$. Genera and species are delineated. 


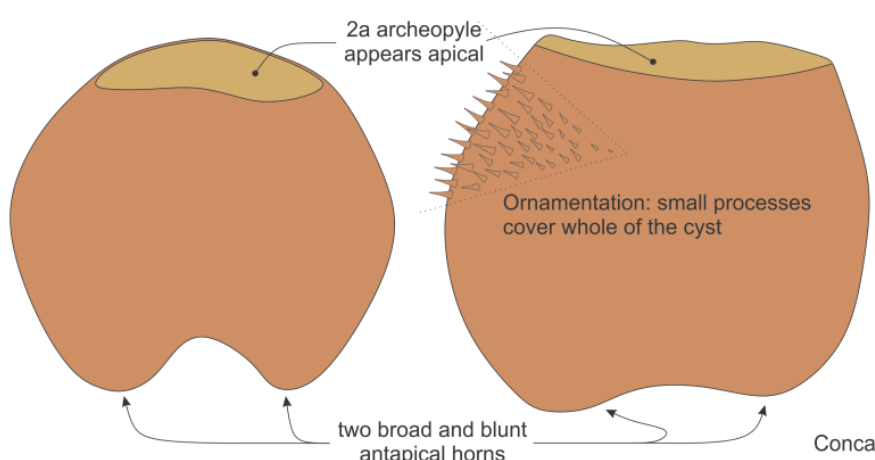
antapical horns

Votadinium calvum Reid Cyst of Protoperidinium latidorsale Sarai et al.

Cyst of Protoperidinium claudicans (Paulsen) Balech

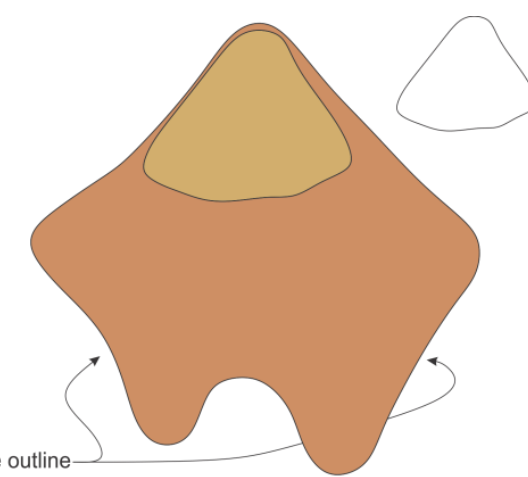

Votadinium concavum sp. nov. Motile stage unidentified
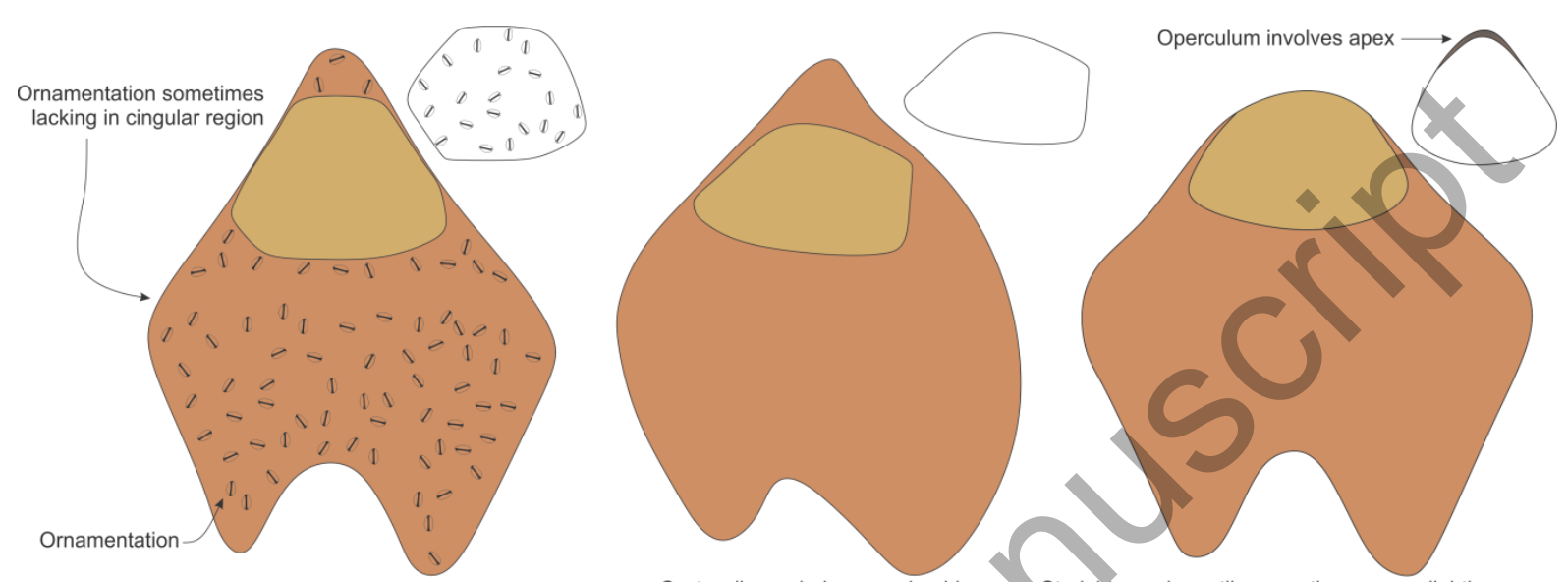

Cyst well rounded, never shoulders Votadinium psilodora Benedek Fossil, motile stage unknown

Straight angular outline, somtimes even slightly concave Votadinium pontifossatum sp. nov.
Cyst of Protoperidinium paraoblongum Sarai et al

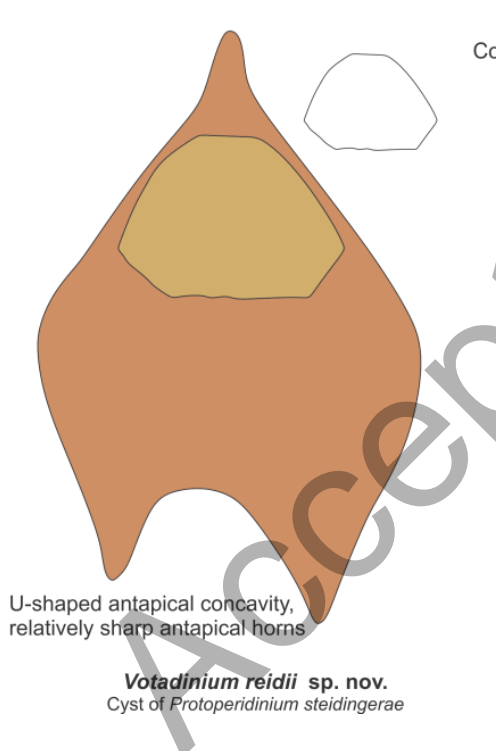

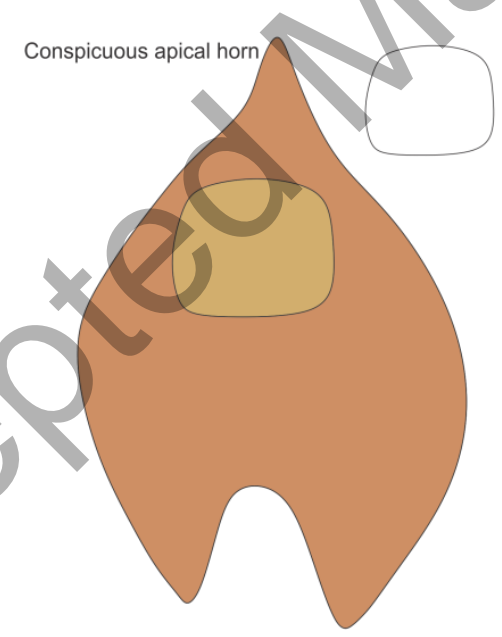

Votadinium elongatum He \& Sun Motile stage unknown
Votadinium rhomboideum sp. nov. Cyst of Protoperidinium quadrioblongum Sarai et al

Fig. 4. Line drawings of Votadinium species as discussed in this paper. 


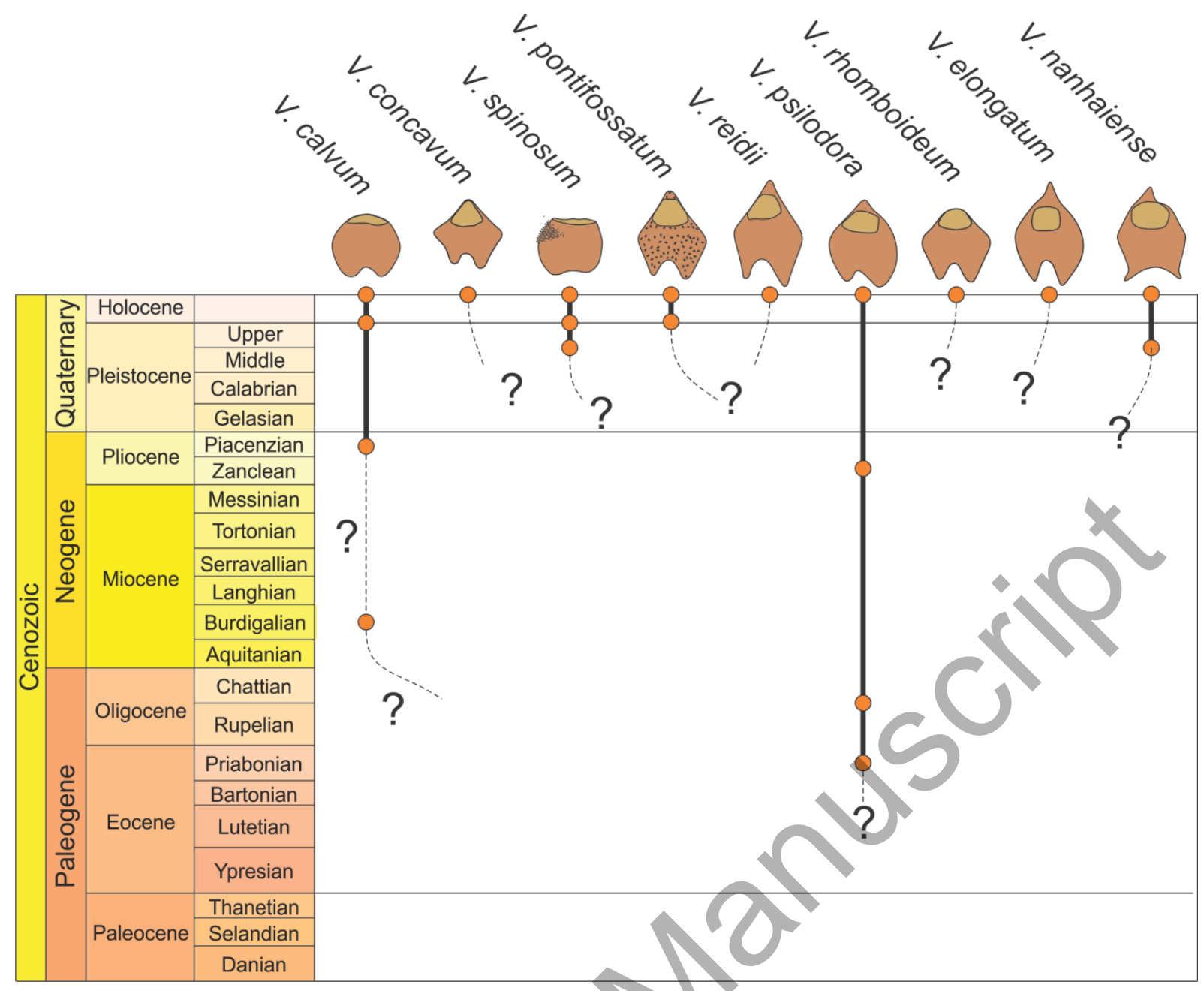

Fig. 5. Fossil record of the genus Votadinium. The reader is referred to the respective entries on distribution and fossil record of the respective species. 

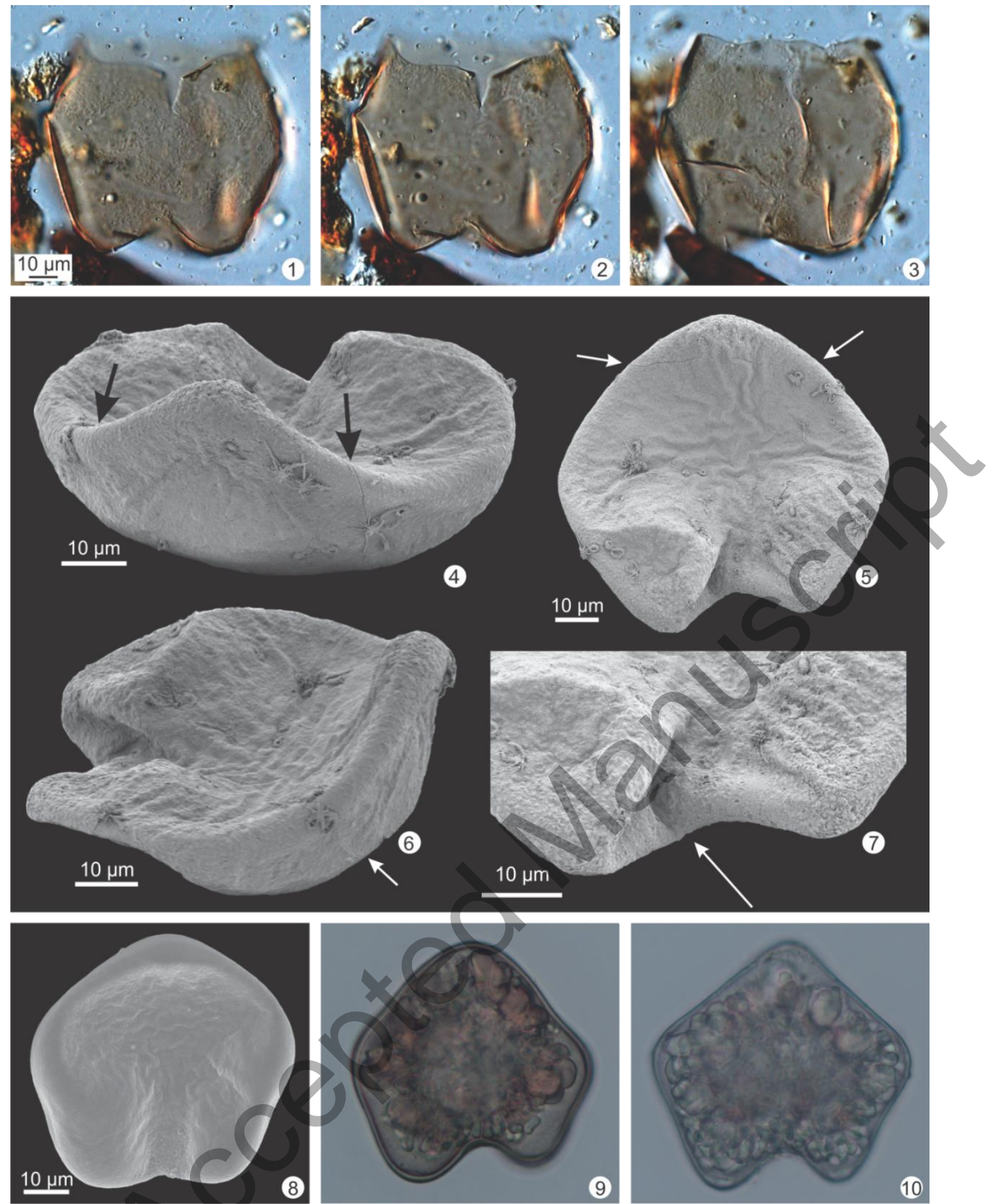

Plate 1. 1-7: Votadinium calvum. 1-3: LM, Kyuquot Sound (UVic 2015-684-1), dorsal view, incrementally lowering focus. 4-7: SEM, the Vilaine Estuary, Bretagne (16C6), 4: oblique apical view; 5 ventral view; 6: lateral view; 7: detail of sulcal area, arrows in 4-6 indicating archeopyle outline, arrow in 7 indicating flagellar scar. 8-10: Votadinium concavum. 8: Holotype, SEM, Bohai Sea, WN142. 9, 10: LM, Bohai Sea, WN142. 

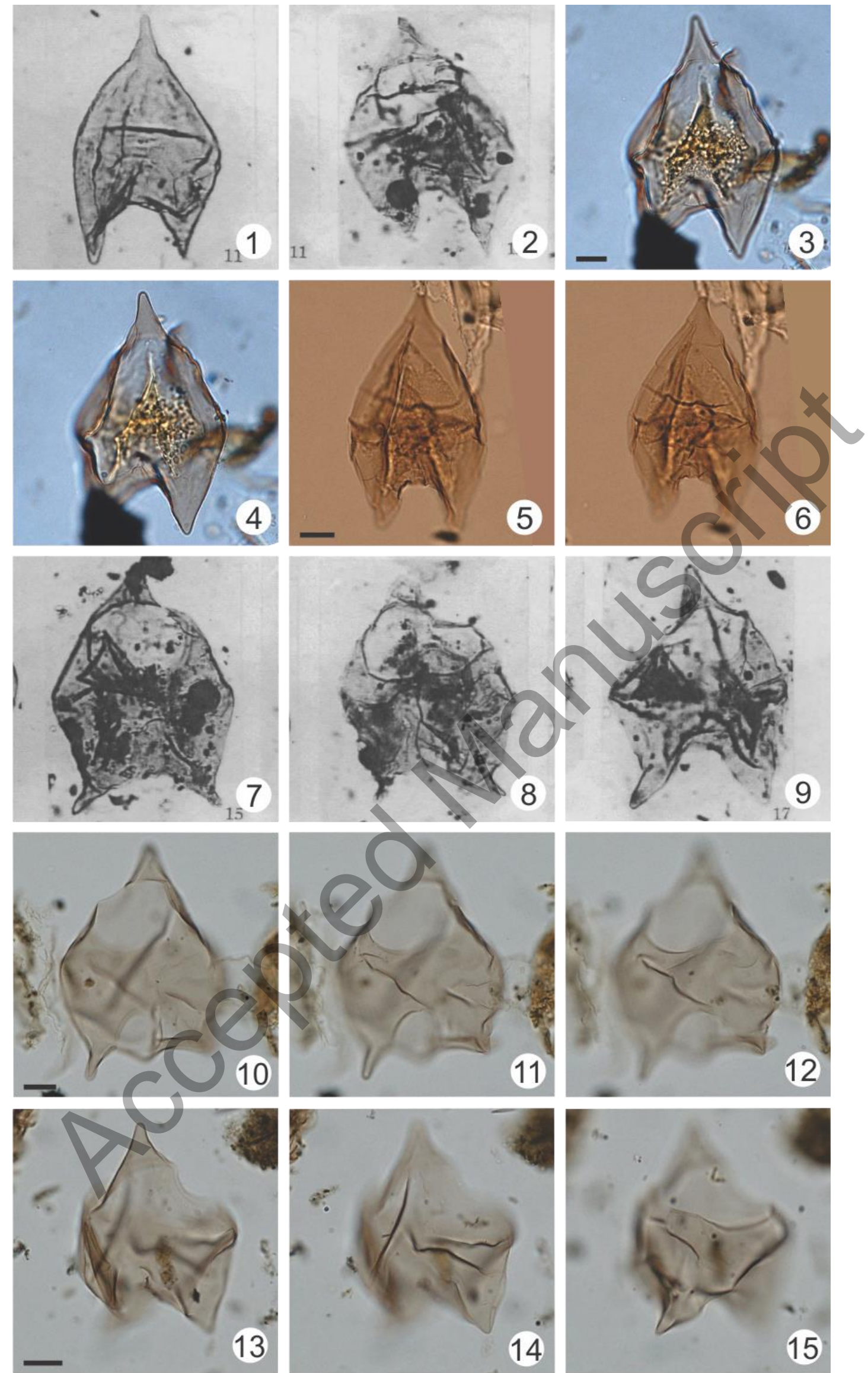
Plate 2. 1-6: Votadinium elongatum from the South China Sea, LM. 1, 2: specimens illustrated by He and Sun (1991, Pl. 2, Figs. 11, 12); 1: Holotype. 3, 4: UVic 2015-287. 5, 6: UVic 2017-11 . 7-9: Votadinium nanhaiense from the South China Sea. 7-9: Specimens illustrated by He and Sun (1991, Pl. 2, Figs. 15, 16 and 17); 8: Holotype. 10-12: UVic 2014149, incrementally lowering focus. 13-15: UVic 2014-112, incrementally lowering focus. 1, 2 and 5-7 are reproduced with permission of Prof. He Chengquan. 


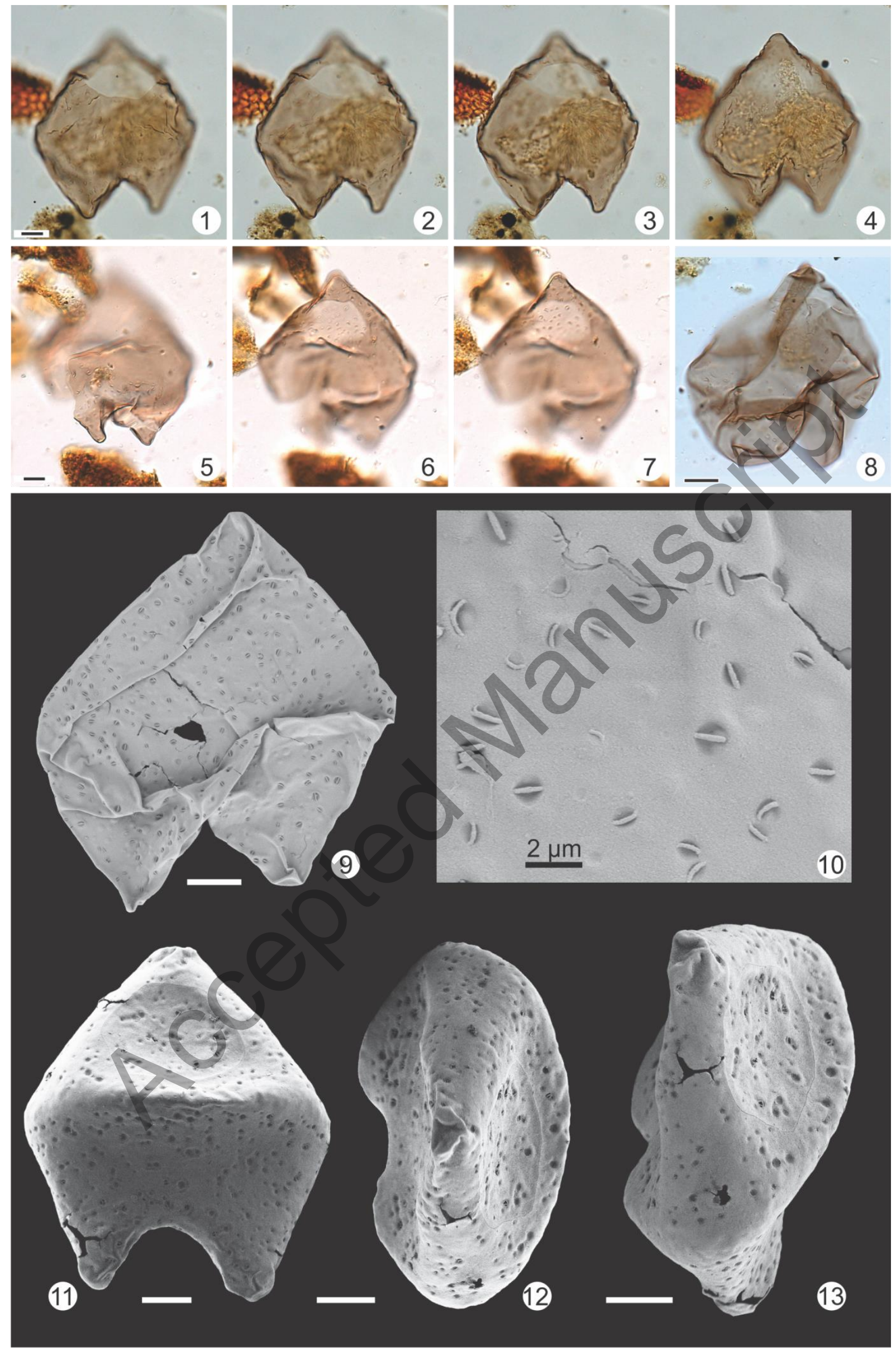


Plate 3. 1-13: Votadinium pontifossatum sp. nov. 1-4: LM, Holotype, 4-5 cm core sample, UVic 2009-179-1, EF. P38/2, incrementally lowering focus. 5-7: LM, Saanich Inlet, surface sediments, UVic 13-326-1. 8: LM, Kyuquot Sound, core sample UVic 2015-622, Holocene, folded ambitus. 9, 10: SEM, Saanich Inlet, surface sediments, UVic 2009-659, 9: folded ambitus, 10: detail of pontifossate ornamentation. 11-13: SEM, Fangchanggang Port, the South China Sea 17G04, surface sediment SCS-FCG, 3D preserved specimen. Scale bars represent $10 \mu \mathrm{m}$ unless indicated otherwise. 

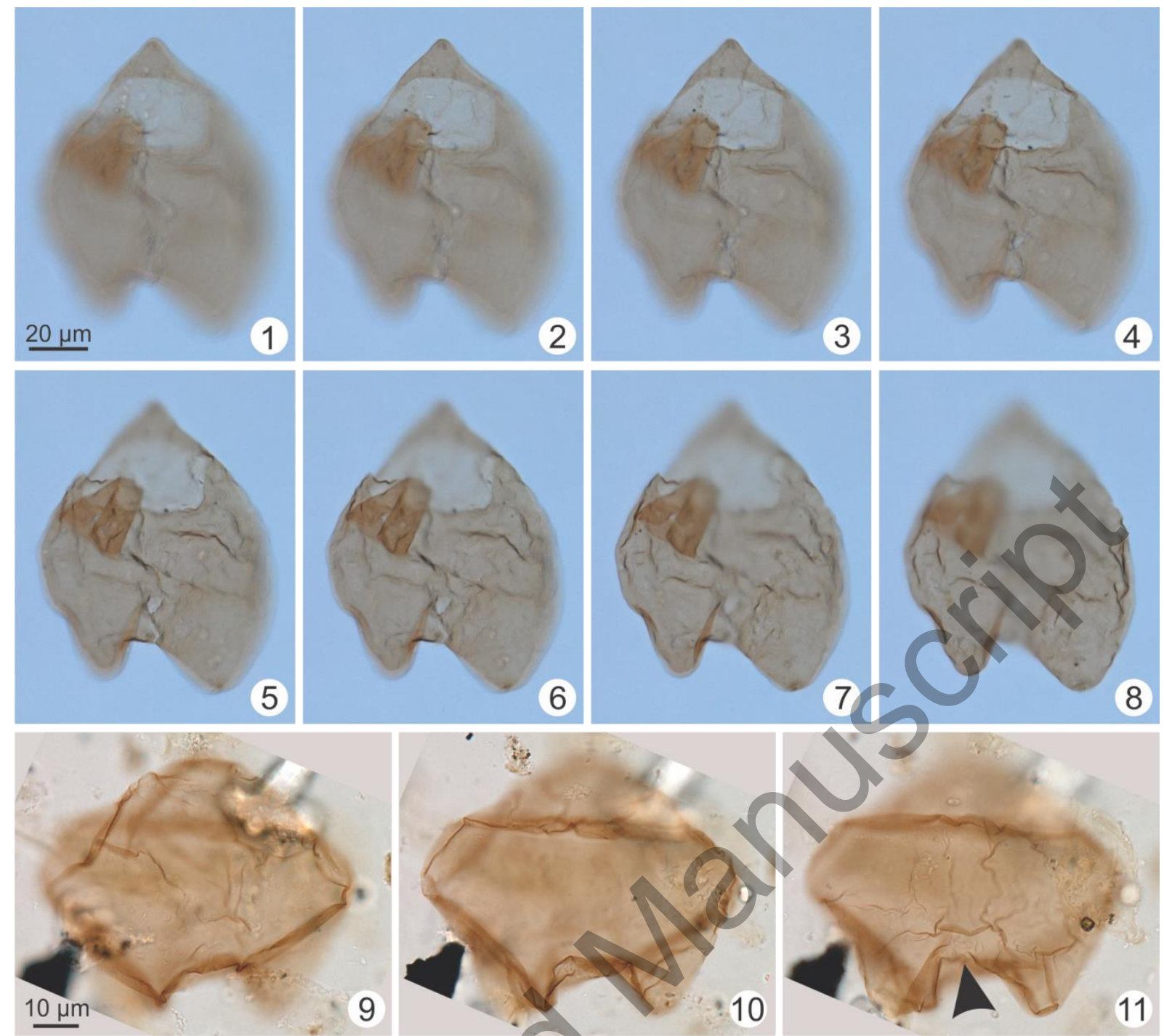

Plate 4. 1-11: Votadinium psilodora comb. nov. 1-8 Holotype, Middle Oligocene, Tönisberg (Germany), single grain slide 747/130, dorsal view, incrementally lowering focus; 9 -11: Slide AK2-2, Akkeshi Bay, Hokaido Province, Japan, incrementally lowering focus. Arrow points to the sulcal depression, as in Matsuoka (1987).

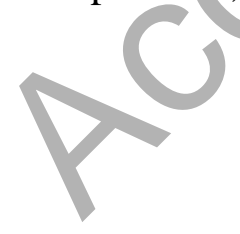



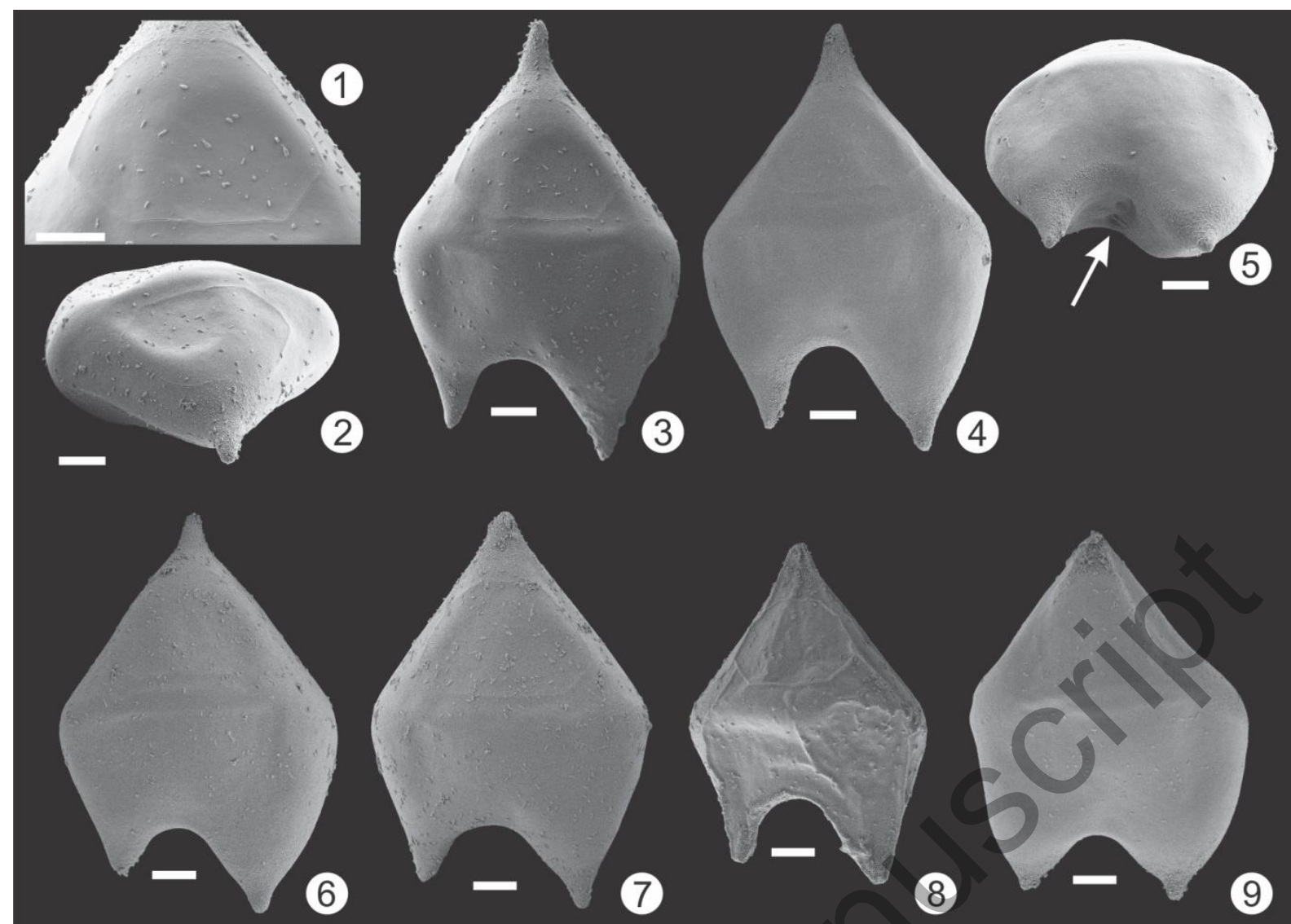

(8)
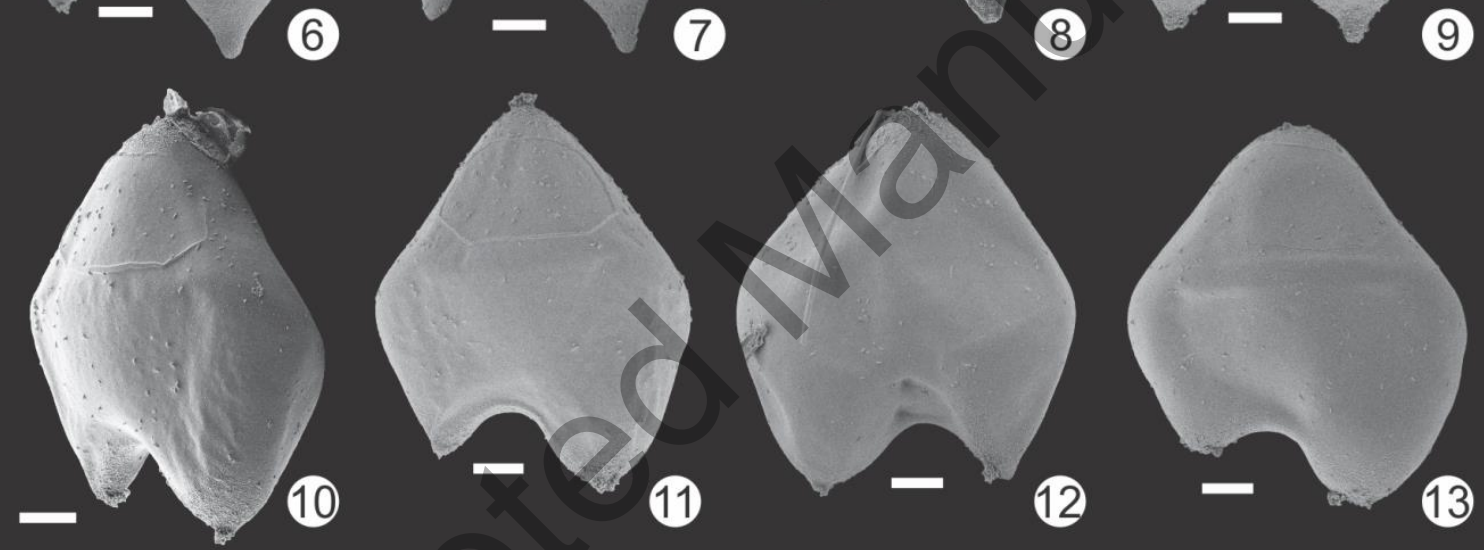

Plate 5. 1-13: Votadinium reidii sp. nov., SEM, sample MV0923-PO-1 from Vineyard Sound, Massachusetts. 1-3: Holotype. 4-13: Illustration of variability. Arrow in Fig. 5 indicates flagellar scar in the sulcal area. Granulae appearing on the cyst wall, especially near (ant)apex is a methodological artifact from SEM coating. 

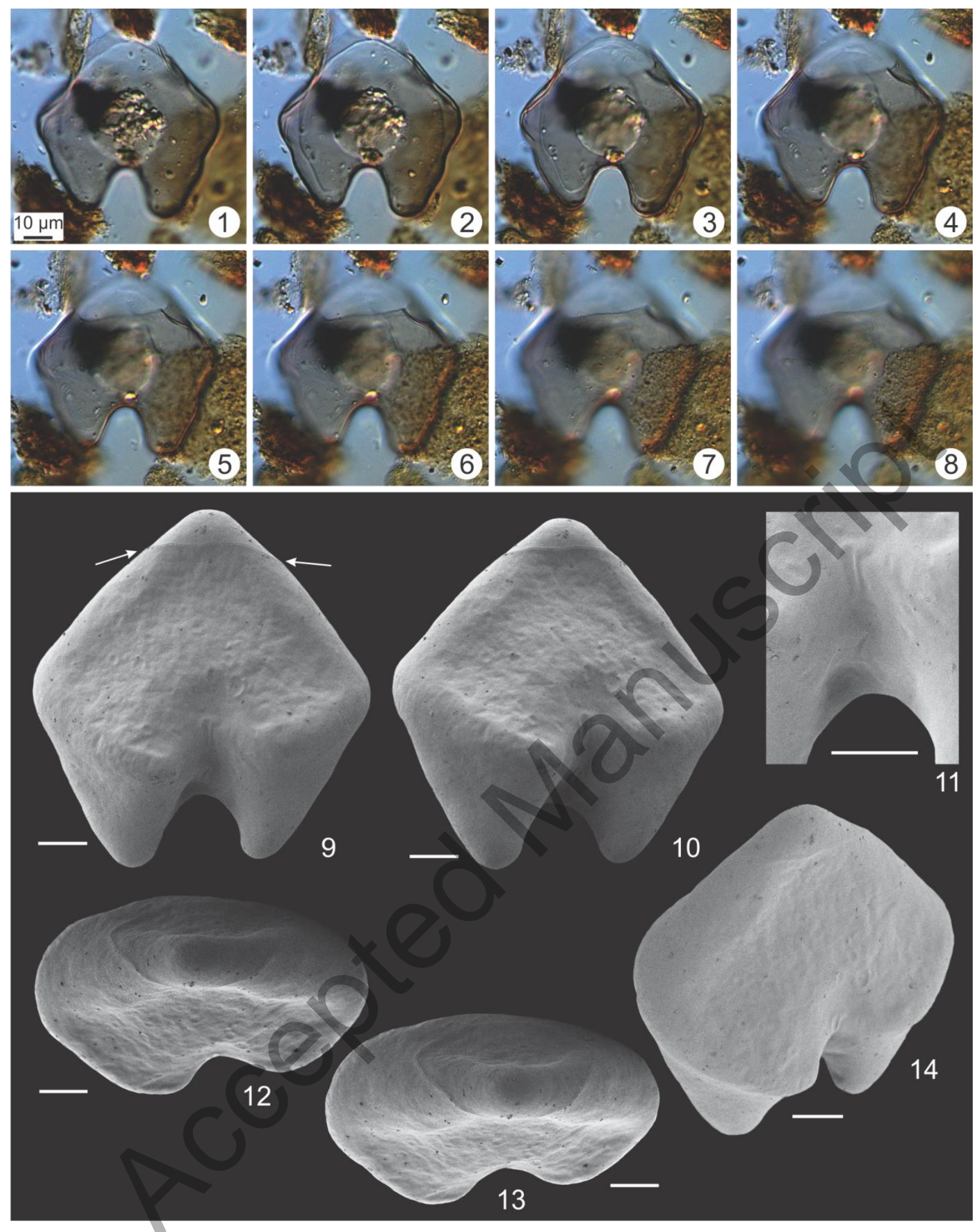

Plate 6. 1-14:. Votadinium rhomboideum. 1-8: Holotype, LM, Saanich Inlet UVic 2012-197-

1 (EF R20/4). 9-14: SEM, the South China Sea CJ17-B703. 9, 10: ventral view, arrows in 9 indicate archeopyle trace; 11: detail of sulcal area showing flagellar scar; 12, 13: apical view; 14: oblique ventral-apical view. Scale bar $10 \mu \mathrm{m}$. 

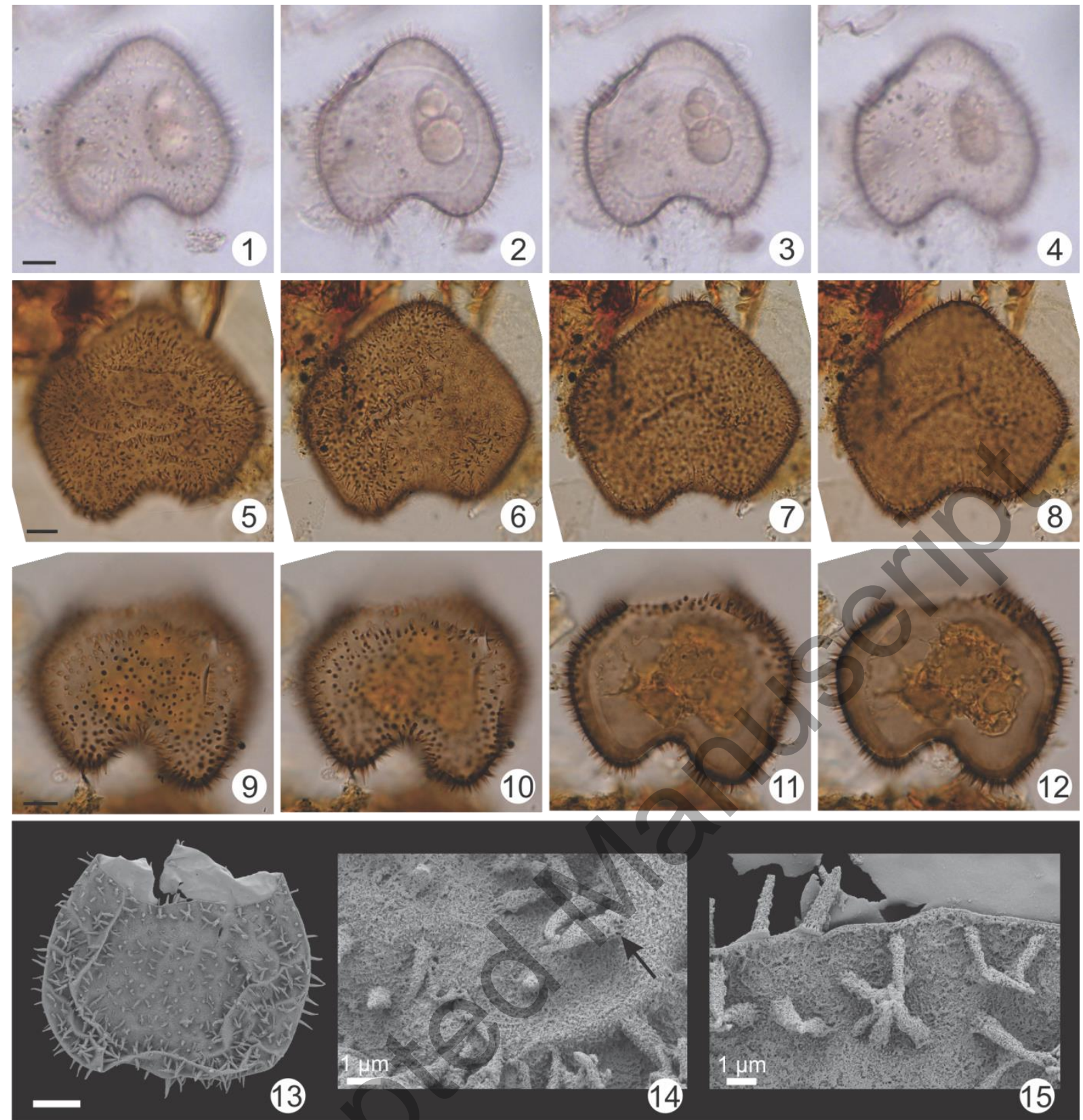

Plate 7. 1-15: Votadinium spinosum. 1-4: Holotype, LM, re-illustrated from Reid (1977), slide 179K4. 5-8: LM, Saanich Inlet, UVic 2009-408-1, incrementally lowering focus; specimen with operculum in place and apex visible. 9-12: LM, off Albert Head near Metchosin in the Strait of Juan de Fuca, UVic 2008-5-1, with archeopyle visible, truncating the apex. 13-15: SEM, Saanich Inlet, UVic 2009-659; 13: ambitus, dorsal view; 14, 15: detail of wall and processes; arrow shows the minute fenestrae at the process bases. Scale bar $10 \mu \mathrm{m}$ unless indicated otherwise. 